\title{
Estrutura do Direito Internacional*.
}

\author{
Braz de Sousa Arruda
}

\begin{abstract}
"O peyor officio que ha no mundo he ser autor de novidades que, muitas vezes, por alguns respeitos, não contentam a muitos homens, porque a cousa que se faz para contentar a muitos he a que descontentar a muitos". (DIogo DE Couto, Soldado Prático, M.D.ccXc.)

" $E$ cara cousa he que aquel que se tem por sabedor redugua a sua mête aa humildade ne crea aquelles que pregam a uerdade, ca aquel que he sandeu, cree que he sabedor 1 .

"International public law is the law of the international community, a turbulent, alive, constantly changing community" 2.
\end{abstract}

\section{Noção de Direito Internacional.}

Já hoje não existe pessimismo cínico sôbre o Direito Internacional como no tempo em que falava sôbre êle

\footnotetext{
* O trabalho que ora se publica não é senão a parte inicial da Estrutura do Direito Internacional que o Prof. BRAZ DE SousA ARRUdA outrora redigira e pretendia por inteiro refundir e ampliar. A morte o impediu de levar a cabo êsse intento. O que se vai ler, embora incompleto, permite verificax o alcance e as proporções dessa obra, que desejava fôsse o coroamento de uma vida dedicada à pesquisa e ao ensino.

1. Orto do Esposo, v. 1, Rio de Janeiro, Instituto Nacional do Livro, 1956, p. 57.

Texto inédito do fim do século XIV ou comêço do XV.

BertTL MALer, em edição do Ministério da Educação e Cultura.

2. Edvard Hambro, $A$ Case of Development of International Law through the international Court of Justice. Law and Politic in the World Community, University of California Press, 1953.
} 
Samuel Puffendorf, Afirmava que outrora Deus se dignava falar aos reis pelos profetas ou por visões; hoje, dizia, conhecemos os seus desígnios pelas circunstâncias favoráveis em que nos coloca para estendermos as nossas fronteiras à custa dos nossos vizinhos; aproveitando essas ocasiões, nada mais fazemos do que obedecer à vontade divina.

Um grande rei, Frederico iI, o Grande, nas instruções para direção da Academia dos moços nobres, definia a função dos Professôres do Direito Internacional: "O mestre advertirá a mocidade que o Direito das Gentes, carecendo de poder coercitivo, é um vão fantasma que os soberanos proclamam para melhor violar".

Salientemos o pensamento de Emmanuel Kant, no seu trabalho Eléments métaphysiques de la doctrina du droit. Assim fala o grande mestre da filosofia: "Quand on songe à la méchanceté de la nature humaine, qui se montre à nu dans les libres relations des peuples entre eux (tandis que dans l'état civil elle est très voilée par l'intervention du gouvernement), il y a lieu de s'étonner que le mot droit n'ait pas encore été tout à fait banni de la politique de la guerre comme une expression pédantesque, et qu'il ne se soit pas trouvé d'état assez hardi pour professer ouvertement cette doctrine. Car, jusqu'à présent, on a toujours cité bonnement, pour justifier une déclaration de guerre, Hugo Grotius, Puffendorf, Vattel et autres (tristes consolateurs) quoique leurs code, rédigé dans un esprit philosophique ou diplomatique, n'ait ou ne puisse avoir la moindre force légale (puisque les États ne sont pas soumis, comme tels, à une contrainte extérieure et commune); mais il est sans exemple qu'un État se soit décidé, par des arguments appuyés sur des autorités aussi respectables, à se désister de ses prétentions. Toutefois cet hommage que chaque État rend à l'idée du droit (du moins en paroles) ne laisse pas de prouver qu'il y a dans l'homme une disposition morale, plus forte encore, quoiqu'elle sommeille pour un temps, à se rendre maître un jour du 
mauvais principe qui est en lui (et qu'il ne peut nier). Autrement les États qui veulent se faire la guerre ne prononceraient jamais le mot droit, à moins que ce ne fût par ironie, et dans le sens où l'entendait ce prince gaulois, en le définissant: "l'avantage que la nature a donné au plus fort de se faire obéir par le plus faible"3.

Progredimos muito depois do grande filósofo da Paz Perpetua.

Grócio, o grande e genial mestre holandês, declara a sociabilidade inata no homem (Prolog., $\S$ 6), reafirmando precisamente o conceito enunciado por Aristóteles, e define o Direito Natural "dictatum rectae rationis".

Célebre é a passagem de Grócıo quando afirma que certas noções jurídicas existiriam mesmo se admitíssimos a inexistência de Deus ("etiansi daremus non esse Deum").

É a Laicização do Direito Internacional, mas de forma superficial, pois Grócio reconhece Deus como origem da lei natural.

Já antes o assunto foi tratado magistralmente por Francisco Suarez (De legibus ac Deo legislatore, L. II, c. VI, $\S 3$ ), em que certamente se inspirou Grócio.

Ainda, mais recentemente, Phillimore se refere à natureza Divina do Direito (Divine Law).

Mas Grócıo ainda sofre a influência do seu tempo e justifica práticas bárbaras que afirma serem permitidas pelo "jus gentium", conquanto contrárias ao "jus naturae".

Hoje os progressos da técnica aumentam cada vez mais a interdependência entre os membros da comunidade internacional e o Direito das Gentes se torna cada vez mais firme e mais efetivo.

A moral e o direito são domínios distintos e separados.

3. Emmanuel KaNT, Éléments métaphysiques de la doctrine du Droit, Traduit par Jules Barni. 
A regra moral se refere a fatos psicológicos, o direito trata da conduta externa. O objeto da ética é espiritual e a sanção moral é interna.

Já dizia Grócio: "Nam justitia securitatem affert conscientiae, injustitia tormenta ac laniatus, quales in tyrannorum pestoribus describit Plato. Justitiam probat, injustitiam damnat proborum consensus. Quod vero maximum est, haec Deum inimicum, illa faventem habet, qui judicia, sua ita post hanc vitam reservat, ut saepe eorum etiam in hac vita representet, quod multis exemplis historiae docent".

Se a sanção do Direito Internacional fôsse moral, chegaríamos à conclusão de Puffendorf, no seu Elementa jurisprudentiae, ou de LoRIMER, para quem, na realidade, não existe absolutamente Direito Internacional Positivo porque não é definido nem o fruto de uma autoridade superior, permanecendo nas mãos dos Estados.

O Direito Positivo (jus positum) é o estabelecido e o Direito Natural é um Direito pressuposto, possivelmente não é obra humana.

O primeiro é obra humana e voluntária (jus humanum; jus voluntarium). O critério é o da efetividade.

Dizer que o Direito Positivo deriva do Direito Natural está em desacôrdo com a experiência jurídica.

O Direito Positivo é o Direito vivo, é o que obriga.

A escravidão é contrária ao Direito Natural; no entanto foi uso comum em vários povos, justificado em várias épocas, não podendo ser contrária ao Direito Internacional Positivo, cujo critério é o uso geral, como dizia Chief Justice Marshall. A Côrte Suprema dos Estados Unidos deu razão às reclamações espanholas e portuguêsas, entregando escravos aos seus legítimos proprietários ${ }^{4}$.

O Direito Internacional está cheio de injustiça e desumanidade, mesmo em tempo de paz.

4. Caso "The Antelope". 
A regra jurídica é obrigatória porque é a expressão de uma ordem jurídica, tornada efetiva pela fôrça de uma autoridade. A autoridade impõe o Direito, ameaçando a maioria com uma coação externa.

$O$ consentimento comum é a expressão de um fato. $O$ Direito pertence ao mundo das realidades empíricas e psicológicas, e não ao mundo abstrato dos valores.

A Comunidade Internacional, mesmo anorgânica tem, uma vontade e impõe sua autoridade. Nenhum Estado é "legibus solutus". A Comunidade Internacional impõe sua vontade.

Afirmamos que o Direito se funda no consentimento comum (Common Consent), que se exprime, em última análise, pelo costume.

Observemos que nos motivos informativos das decisões se encontram fatores livres, além da lei e do costume. Não são as fontes definidas que são levadas em consideração em casos concretos. Recorrem os que decidem da aplicação do Direito ao que se denomina Princípios Gerais de Direito, ideal jurídico, Direito científico, Direito justo etc..

Quando o Estatuto da Côrte se refere (no art. 38, c) aos princípios gerais de Direito reconhecidos pelos povos civilizados, tem em vista princípios fundamentais comuns à civilização humana, reconhecidos pelos direitos internos dos vários países, "verbi gratia", máximas processuais, regras sôbre nulidades de contratos, direitos fundamentais da pessôa humana... O mesmo poderíamos dizer do art. 38 (na parte $d$ ) o que se quer ocultar é que a Côrte cria direito, não se limita a aplicá-lo.

$\mathrm{Na}$ decisão judicial há criação de Direito.

A Côrte Internacional de Justiça, criada em Haia no Palácio da Paz, em 18 de abril de 1946, desempenha papel decisivo na formação de Direito Internacional na atualidade.

Esta doutrina é defensável, mesmo em face do art. 59, segundo o qual a decisão da Côrte é obrigatória só para as partes em litígio. 
A decisão é "res judicata" para as partes mas os motivos da decisão criam precedentes, cuja autoridade é incontestável.

A Côrte interpreta os tratados e foi ela que fixou em 1948 a natureza jurídica da $\mathrm{ONU}^{5}$.

O Direito Internacional é um conjunto de normas que regulam as relações internacionais. Refere-se, como veremos, a normas jurídicas que conferem a condições de fato o caráter de atos lícitos ou ilícitos. $O$ ato ilícito não é a violação e nem a negação do Direito. É um comportatamento humano definido pelo Direito como a condição de uma coação determinada pelo próprio Direito. $O$ ato ilícito é seguido de uma coação mas esta afeta, em regra, não o autor do ato, mas sim outros indivíduos.

O Estado, conjunto de indivíduos, é responsável por atos de seus órgãos: responsabilidade por atos ilícitos cometidos por terceiros. O caráter de primitivismo é patente no Direito Internacional ${ }^{6}$.

Para nós, a teoria do Direito das Gentes tem por objeto o Direito Internacional Positivo. É, contudo, um pressuposto que a norma de Direito Positivo corresponde aos princípios comuns, considerados como obrigatórios no mundo civilizado.

O Direito Internacional Positivo expressa as idéias dominantes em dado momento no mundo civilizado e sofre a influência de uma evolução histórica.

A aplicação da norma depende de fato psicológico mas não podemos aceitar a afirmação "Lex facit regem", com Cardoso, no Nature of Judicial Process, que reduz o Direito a sentenças isoladas. Isto não quer dizer que consideramos o critério da efetividade como inconcludente. Acima de regras imperativas, existem em tôda ordem jurídica princípios estruturais que, sem serem obrigatórios são efe-

5. Réparation des dommages, c.I.J., Recueil 1949, p. 178.

6. LAUTERPACHT, The function of Law in the international community, 406. KELSEN, R.C.A., IV, 131. 
tivos. É porque podemos afirmar que a Constituição verdadeira não é a escrita (nos Estados em que existe), mas sim a Constituição viva.

É o critério da efetividade.

Hans Kelsen, the leading jurist of the time (Roscon Pound), o chefe da Escola de Viena, o criador da teoria pura do Direito, a mais significativa e persuasiva, o mais alto desenvolvimento da Filosofia de Direito no século $\mathrm{xx}$, diz muito bem: "Whatever is considered "just" in the sense of international morality has at least a tendency of becoming International Law"7

O Direito sofre a influência da moral e não se aperfeiçoa sem uma reforma no espírito dos homens: de nada vale reformar as leis se não se reformam os costumes.

\section{Definição de Direito Internacional.}

O Direito tem como escopo possibilitar a convivência na coletividade. Já dizia Santo Tomaz, repetindo Santo Agostinho: Pax est ordinata concordia.

Se o Direito garante a paz, não garante uma paz absoluta porque não garante a ausência de todo recurso à fôrça. Estabelece, ao contrário, o monopólio da fôrça em proveito da comunidade jurídica.

Hoje diz Kelsen, na sua Law and Peace in International Relations: "Law is essentialy an order for the promotion of Peace".

O Direito Internacional regula as relaçôes dentro da comunidade internacional. O grande Pedro Lessa definia o Direito como conjunto orgânico das condições de vida e desenvolvimento de indivíduos e da sociedade, dependentes da vontade humana e garantidas, ou que o deveriam ser, pela fôrça coercitiva do Estado.

7. Hans Kelsen, Law and Peace in International Relations. 
o Direito Internacional seria, portanto, um conjunto orgânico das condições de vida e desenvolvimento dos Estados que compõem a comunidade internacional, consideradas legalmente obrigatórias por êstes Estados e sancionadas, ou que o deveriam ser, por uma fôrça coercitiva, isto é, pela fôrça coercitiva dos Estados da comunidade internacional.

\section{Definição de Oppenheim.}

No seu Tratado de Direito Internacional, OpPenheIm o define: "Law of nations or International Law (Droit des gens, Völkerrecht) is the name for the body of costumary and conventional rules which are considered legally binding by civilised States in their intercourse with each other".

Direito Internacional seria para êle êste corpo de regras costumeiras e convencionais, consideradas legalmente obrigatórias pelos Estados civilizados em suas relações recíprocas.

Hoje já não poderíamos afirmar que o Direito Internacional regula ùnicamente as relações que se estabelecem entre os Estados da comunidade internacional.

Outros autores, com pontos de vista diversos, conceituam o Direito Internacional de forma diferente.

O célebre Sir Henry Maine, na sua International Law (1883), diz: "O Direito das Gentes é um sistema complexo composto com vários ingredientes. Consiste em princípios gerais de direito, de justiça, que serviriam para conduta dos indivíduos num Estado de eqüidade natural, e para conduta das nações, coleção de usos e costumes, opiniões, desenvolvimento do comércio e da civilização e um código de Direito Positivo".

Hoje, Jean L'Huillier define o Direito Internacional, no seu Éléments de Droit International Public, Paris, 1950: “Le Droit International Public a pour objet de régler les 
relations juridiques mutuelles d'un ensemble de colectivités indépendantes c'est-á-dire que ne sont pas soumises $\dot{a}$ une autorité politique commune".

Podestà Costa diz: "El Derecho Internacional es el conjunto de normas que rijen las relaciones de los Estados entre sí y tambien las de estas con ciertas entidades que, sin ser Estado poseen la personalidad juridica internacional".

De um ponto de vista inteiramente diferente, LUIS LE FUR afirma: "É a determinação da competência das pessoas jurídicas efetuada conforme o bem comum por uma autoridade e garantida eventualmente pela aplicação de sanções positivas"?.

Para êle, o Direito tem caracteres essenciais, a efetividade e a conformidade com a justiça, o que tem por conseqüência um dualismo jurídico, levando-nos a distinguir entre o Direito Natural ou Objetivo e o Direito Positivo.

Não nos podemos esquecer de definir o Direito e o Direito Internacional de acôrdo com o eminente mestre Vicente Rao, na sua obra $O$ direito $e$ a vida dos direitos.

Comecemos pela Noção de Direito: “... é o direito um sistema de disciplina social fundado na natureza humana que, estabelecendo, nas relações entre os homens, uma proporção de reciprocidade nos poderes e nos deveres que lhes atribui, regula as condições existenciais e evolucionais dos indivíduos e dos grupos sociais e, em conseqüência, da sociedade, mediante normas coercitivamente impostas pelo poder público".

Conceitua Vicente Rao o Direito Internacional: “ .bem se pode definir cientificamente o Direito Internacional como sendo um sistema de princípios e de normas que, imposto pela consciência geral, ou por fôrça de convenções ou tratados, e sancionado pelas organizações consti-

8. Derecho Internacional Publico, 3. ${ }^{\mathrm{a}}$ ed. 1955.

9. Essai d'une definition synthétique du Droit, Bulletin de la Societé de Législation comparée. 
tuídas entre os povos livres, regula as relações entre as nações, entre estas e as pessoas de nacionalidade diversa, ou entre estas pessoas, atribuindo-lhes uma reciprocidade de direitos e de obrigações e estabelecendo, por êste modo, os meios existenciais e evolucionais da comunhão universal, baseada no reconhecimento dos direitos fundamentais do homem e na segurança da Paz".

\section{Definição aceitável.}

De um ponto de vista geral, podemos dizer que o Direito Internacional é um corpo de costumes, regras e princípios reconhecidos como obrigatórios pelos Estados e outras pessoas internacionais nas suas relações recíprocas.

O Direito Internacional regula as relações que se estabelecem dentro da comunidade internacional.

Vejamos agora o ponto de vista soviético.

A teoria Soviética do Direito Internacional sofreu transformações dramáticas através dos tempos. A doutrina e a prática se entrelaçam e se chocam diante da política da Rússia Soviética.

Não vamos, no momento, examinar com HaNs KelSEN, no seu Direito Internacional Soviético, estas transformações porque isto nos levaria muito longe. Deixemos de parte o periodo de transição que vai até 1930 . Não acompanhemos as divergências doutrinárias processadas entre 1937 e 1950. Basta-nos uma clara noção do que vem a ser hoje Direito Internacional Soviético, ou Direito Internanacional na opinião atual da doutrina da U.R.s.S..

o Direito pode ser definido: "A regra de conduta do povo como expressão da vontade da classe dirigente, ordenada ou sancionada pelo Estado e protegida pelo seu poder de mando para o fim de proteção, estreitamento e desenvolvimento de relações públicas, com vantagem para a classe dirigente". 
O Direito Internacional atualmente é considerado uma superestrutura da base econômica socialista e capitalista.

Futuramente a base socialista prevalecerá e então surgirá um Direito Internacional Universal de caráter socialista ${ }^{10}$.

De acôrdo com a política soviética existiriam três tipos diferentes de Direito Internacional. Primeiro, um sistema capitalista, que regula as relações entre os Estados capitalistas; segundo, um sistema socialista, que regula as relações entre os Estados socialistas; e, finalmente, um sistema comum regulador das relações entre os Estados capitalistas e socialistas.

Korovin, que aderiu a esta orientação, afirma que, entre êstes sistemas de Direito Internacional, pode haver identidade de regras: não matar, não furtar ${ }^{11}$.

Este ponto-de-vista tem sido muito atacado. Numa discussão da Academia de Ciências Sociais do Comité Central do Partido Comunista da Rússia Soviética, juntamente com a divisão de Direito Internacional do Instituto Jurídico da Academia de Ciências da U.R.S.s., Moscou 1952, em que participaram os maiores juristas, chegou-se à conclusão de que só existe um sistema universal de Direito Internacional, com regras igualmente obrigatórias para os Estados socialistas e capitalistas.

Korovis confessou-se vencido e declarou que existe um só sistema de Direito Internacional, baseado principalmente nos tratados internacionais. Acrescentou que as regras geralmente reconhecidas de Direito Internacional fazem parte da superestrutura socialista ou burguesa.

Konoviv enuncia uma nova definição de Direito Internacional: coleção de regras que regulam as relações entre os Estados, protegidas por êles, desenvolvidas no curso da

10. KozhevNikov, Nekotorye Voprosy Mezdunarodnovo Prava, o que vem a ser: Questões de Direito Internacional.

11. KoRovin, Ob Obschepriznannyh Normah Mezdunarodnovo Prava. 
cooperação ou da luta, tendo por escopo a satisfação das necessidades materiais e espirituais no interêsse das classes dominantes nos Estados.

Atualmente podemos afirmar que a definição de Direito Internacional dominante na Rússia Soviética é a de VICHINSKY.

Diz êle: "Direito Internacional é o conjunto de regras reguladoras das relações entre os Estados, seja no decurso de cooperação ou de luta, como expressão da vontade das classes dirigentes dos Estados, asseguradas pela coação individual ou coletiva dos Estados".

O Direito Internacional e suas regras tradicionais têm obrigatoriedade reconhecida pela doutrina jurídica soviética e baseiam a coexistência entre os dois sistemas políticos do mundo.

Cinco princípios norteiam a política Soviética:

1. respeito mútuo ao território e à soberania dos Estados;

2. obrigação de não atacar outros Estados;

3. não-intervenção nos negócios internos dos outros Estados;

4. igualdade internacional;

5. coexistência pacífica.

\section{Objeto.}

O conjunto de regras jurídicas que regem a organização e as relações da sociedade internacional é que é o direito das gentes ou internacional.

Vejamos, antes de mais nada, a origem da expressão Direito das Gentes. Foi ela empregada nos séculos XvI e xvII com dupla significação.

1. O Direito que todos os povos devem observar entre si (inter se), Direito que se impõe a êles e não pode 
ser modificado unilateralmente por um Estado que aja isoladamente.

2. Conjunto das leis análogas em tôdas as nações (jus intra gentes). Estas leis podem ser modificadas como se fôssem legislação interna.

$\mathrm{Na}$ primeira acepção, foi usada a expressão Direito das Gentes quando o francês substituíu o latim: "droit des gens".

Nos séculos XIII e xIv a influência da França na Inglaterra é enorme. São LuIs influenciou já Eduardo I. No reino do Henrigue iII, é a língua do direito escrito e, no de Eduardo I, já era a língua dos Tribunais ${ }^{12}$.

A obra célebre de VATTel (1758) intitula-se: "Le droit des gens ou l'ensemble des principes de la loi naturelle appliqués ḋ la conduite et aux affaires des nations $e$ des souverains".

A expressão Direito Internacional, nos fins do século xviII, começa a predominar. Quem primeiro usou a expressão Direito Internacional (International Law) foi BenTHAM em 1780, ao traduzir o trabalho célebre de ZoucH, publicado em 1650: "Juris et judicis fecialis sive de jure inter gentes et quaestionum de eodem explicatio".

Hoje predomina a expressão Direito Internacional conquanto alguns autores prefiram usar Direito das Gentes.

Quanto ao objeto do Direito Internacional, trata êle:

1. das regras que se impõem aos Estados nas suas relações recíprocas

12. William StuBbS, Histoire constitutionnelle de l'Anglaterre. Literatura: Sir HERSH LAUTERPACHT, The development of I.L. by the Int. Court, 1958. R. Jennings, The Progress of I.L., B.y.B., 1958, p. 334 - 55. Edward Hambro, A Case of Development of I.L. through the $I$. Court of Justice - University of California Press, 1953. Il Diritto della Energia Nucleare, Milano, 1961. Publicação do Centro Internazionale di Studi e Documentazione sulle comunità Europee. Problemes juridiques et administratifs de la protection dans l'emploi pacifique de l'energie nucleaire. - Actes officiels de la Conférence Internationale tenue a Bruxelles du 5 ou 8 septembre 1960. Bruxelles - 1961 . 
2. regras relativas à constituição e ao funcionamento das organizações internacionais, criadas pelos Estados.

o Direito Internacional, como todo Direito, tem uma parte estável e outra evolutiva. O Direito caracteriza-se essencialmente pela estabilidade. $O$ dinamismo, no entanto, é hoje elemento poderoso na coletividade internacional.

Deve-se a transformação rápida do Direito das Gentes a vários fatores. Em primeiro lugar, aumenta o número dos Estados independentes dentro da coletividade internacional. Êstes Estados são de nível cultural muito diverso. Expande-se, portanto, quantitativamente e qualitativamente a comunidade internacional.

No Direito Internacional clássico, só eram sujeitos os Estados civilizados. Hoje surgiram as organizações internacionais.

A onU é verdadeiro sistema solar, que agrupa número enorme de organizações especializadas. Estas organizações são instrumentos de cooperação entre seus membros. Instrumentos de trabalho, as organizações internacionais têm personalidade jurídica.

3. Os indivíduos eram considerados objeto do Direito Internacional, os Estados os sujeitos.

Hoje, o Direito Internacional se ocupa do estatuto jurídico do indivíduo, mesmo no Estado de sua nacionalidade. Em 1919, é criada a Organização Internacional do Trabalho; em 1945, a Ciarta das Nações Unidas inscreve no seu texto a proteção do direito do homem.

4. Os progressos técnicos e científicos fazem surgir novos problemas no campo do Direito Internacional. Para êste aspecto do Direito das Gentes já chamei a atenção em trabalho publicado na Revista da Faculdade de Direito.

$O$ que caracteriza a nossa época é vivermos em uma civilização técnica. Novas fontes de energia, conquista dos espaços celestes, contrôle dos fatores metereológicos e cli- 
matológicos, verdadeiras revoluções científicas e técnicas que exigem revisão de conceito. A energia atômica, a conquista dos espaços celestes, a televisão têm influência direta no campo internacional.

É impossível imaginar o que será a televisão dentro de dez anos. Foram necessários cinco séculos para que a imprensa se transformasse com progressos decisivos (rotativa etc.). Esperemos a côr, o relêvo, os sons do universo, a ligação do mundo conhecido ao desconhecido.

\section{Características do Direito Internacional.}

Em regra, o Direito existe nos quadros do Estado, em uma sociedade onde o mando é exercido por um Poder Supremo, ao qual estão submetidos os indivíduos a quem se aplica o Direito.

É uma sociedade em que existe um Poder Supremo, a Soberania ou Poder incontrastável de querer coercitivamente e de fixar as competências.

Em conseqüência:

1. O Direito elaborado pelo legislador impõem-se a todos.

2. O respeito ao Direito é assegurado pelos tribunais, cujas decisões aplicam e interpretam o Direito.

3. A sanção de Direito é assegurada pela autoridade pública por meio de várias formas de coação.

4. O uso da fôrça material é proibido aos particulares; o Estado tem o monopólio da fôrça.

No Direito Internacional que se aplica essencialmente às relações entre os Estados, não existe autoridade superior organizada na sociedade internacional.

Os Estados são soberanos e a sociedade internacional é composta de Estados soberanos. 
Temos:

1. que a elaboração de Direito se faz pela ação de Estados porque não existe autoridade legislativa superior.

2. A intervenção de juiz pressupõe um acôrdo dos Estados interessados.

3. A sanção de Direito é imperfeita: não existe, em regra, sanção penal e a sanção é assegurada pelos próprios Estados.

4. O Direito de usar a fôrça é reconhecido aos Estados e o Estado forte está em condições de assegurar mais o Direito do que o Estado fraco.

É por isto que na onU existe - e não poderia deixar de existir - a preeminência de Grandes Potências.

As condições de formação e de aplicação do Direito são diferentes na vida internacional e na sociedade etática.

Temos que salientar ainda que o elemento político atua muito na aplicação das regras de Direito Intenacional.

A armadura técnica do Direito Internacional é fraca e, muitas vêzes, os elementos extra-jurídicos tornam a sua aplicação precária.

Muitos autores, como Austin, consideram o Direito Internacional como um conjunto de regras morais, o que não é verdade.

Os Estados e as organizações internacionais consideram-se obrigados jurìdicamente e não simplesmente por normas morais.

Evolução das relações internacionais.

Temos que salientar que, em cada periodo histórico, as relações de poder se enquadram em um sistema:

a) mando de um - Roma;

b) mando de ninguém - equilíbrio; 
c) de vários - diretório das Grandes Potências;

d) mando de dois - mundo bipolarizado (Rússia, América do Norte).

Quando o ator universal se impõe, converte-se em um sistema político de base constitucional, firmado na cooperação entre os antigos atores.

No caso do sistema de "liberum veto", um dos atores possui uma arma definitiva (bomba atômica - Os sinos de Nagasaki, de Paulo Nagai).

Enquanto houver Estados independentes, haverá distinção entre questões jurídicas e políticas.

A técnica jurídica nunca poderá substituir a diplomacia. A base normal da política externa é o ajuste contínuo dos interêsses políticos e não se trata de pleitos que terminem em uma Sentença ${ }^{13}$.

Daí se conclui que a diplomacia da estratégia e a estratégia da diplomacia são inseparáveis.

A base da diplomacia é a transação na negociação: "Il faut négocier et toujours négocier", como dizia TALLEYRAND.

Nas suas origens, a diplomacia desenvolve-se em um mundo homogêneo, onde, pela negociação, se consegue a guerra limitada. Negociar em vez de lutar é sempre possível quando a guerra não é total. Esta só se resolve com a rendição incondicional e a condenação dos vencidos.

Não é só a guerra de agressão que é punida, mas também a guerra perdida ${ }^{14}$.

O mesmo sustenta Winston Churchill. ${ }^{15}$.

Será $a$ ond ordem juridica?

O Direito não é certo, não é perfeito, mas existe e disso temos consciência.

13. MoRehenthaU, Diplomacy, Yale Law Journal, 1945.

14. Marechal MoNTGOMERY.

15. N. vi, p. 631. The second World War. 
Que uma norma jurídica tenha só uma significação, que haja uma única interpretação, certa e segura, é pura ficção para manter a ilusão da segurança social.

Sòmente em uma organização internacional é possível a segurança jurídica, como na oNu.

A oNU é a aspiração máxima do gênero humano na construção de um sistema que estabeleça a paz e a justiça entre os homens e as nações: "Law is essentialy an order for the promotion of peace" 16 .

Pressupostos sociológicos do Direito Internacional.

I.

\section{Comunidade Internacional.}

A existência do Direito das Gentes pressupõe uma Comunidade Internacional. Esta é uma realidade sociológica, composta de Estados, ligados por interêsses materiais e espirituais.

É de sua natureza que o D.r. não se aplique diretamente aos indivíduos. Isto não significa que êstes, excepcionalmente, não possam ser sujeitos do Direito das Gentes.

Se não existisse uma Comunidade Internacional, não existiria o Direito que lhe é próprio.

Com os progressos da técnica, cada vez mais se consolida a Comunidade Internacional, pelo entrelaçamento dos interêsses comuns, interêsses humanos.

O D.I. garante hoje, não só os interêsses políticos dos Estados, mas também os interêsses espirituais.

Isto fica bem claro quando se estuda a posição internacional da Cidade do Vaticano.

16. KEISEN, The Law of U.N.. 
A Constituição da Organização Internacional do Trabalho é outra demonstração de que o Direito das Gentes moderno evolui no sentido de modificar a doutrina tradicional que afirma que sòmente os Estados tomam parte no processo de criação das normas internacionais e que sòmente os interêsses dos Estados são diretamente representados na esfera internacional.

De acôrdo com a Carta, a Organização das Nações Unidas é uma organização de Estados. A Organização Internacional do Trabalho obedece a princípios diferentes.

II.

Estados soberanos.

Esta Comunidade Internacional é composta de Estados independentes ou soberanos. A soberania não é um mito, mas representa alguma coisa de real.

Se o D.I. se funda, como Direito da Comunidade Internacional, na existência de Estados soberanos, devemos definir o Estado soberano com notas que estão fora do campo jurídico. Assim poderemos afirmar que o Estado soberano é uma comunidade que se governa plenamente a si mesma e é independente de outros Estados.

"Souveränität ist der Sachverhalt, das Staaten von den in ihrem Substrat zur sozialen Gesamtheit zusammengeschlossenen Einzelmenschen als deren bzw. deren Gesamtheit Organ (im untechnischen Sinne) nämlich als Normenquelle and evtl. auch (so vor allem im Völkerrecht) als Normenadressat eines Rechtes geschaffen bzw. anerkannt werden, and dass dann die Staaten hinaindtlich der Schaffung dieses Rechtes auf Grund jener allgemeinen Kompetenz, jenes Zurechnungsprozesses für sich nun ihrerseite nicht auch wieder eine andere juristische Person, sondern nur sich selbst bzw. zumindestens auch sich selbst (ihre Mitbeleiligung) für die Schaffung des Rechtes gelten lassen, und dass die Staaten hinsichtlich der Geltung jenes Rechtes 
(insonderheit des Völkerrechts) auf Grund jener generellen Kompetenz, jenes Zurechnungsprozesses, weder die Einzelmenschen, noch für sich eine andere juristische Person, sondern nur sich selbst bzw. auch sich selbst als Normenadressaten, Zurechnungspunkte für die subjektiven Rechte und Pflichten jenes objektiven Rechtes gelten lasse. Kurs: Souveränität hat der Staat, insofern und insoweit er Zurechnungs-Endpunkt ist"17-18.

Esta moxinifada mostra bem o que é a filosofia alemã, tão bem espelhada na peça $O$ Jovem Telêmaco.

O essencial da doutrina de KnubBen é a frase: "não a própria soberania, mas a competência, isto é, a competência sôbre a soberania, é o essencial e o critério da distinção do Estado diante de tudo que não seja estatal".

É competência sôbre a competência simples que cabe ao Estado soberano.

Veja-se sôbre soberania, com muito proveito, o curso de Korowicz ${ }^{19}$.

17 Knubben, Die Subjekte des Völkerrechts, 173.

18. Knubben, Os sujeitos do Direito das Gentes.

"A Soberania é um conjunto de fatos por fôrça do qual Estados serão criados e reconhecidos pelos indivíduos agrupados, no seu substrato, em uma comunidade social (em sentido não técnico) como órgão dos mesmos e da sua comunidade, isto é: como fonte de normas e, eventualmente, também (assim, sobretudo, o Direito das Gentes) como destinatário de normas de um direito e que, em conseqüência, os Estados, quanto à criação dêste direito, devido àquela competência geral, àquele processo de imputação, reconhecem doravante como válido para si mesmos e não para outra pessôa jurídica, mas exclusivamente também para si próprio (sua co-participação), e que os Estados, quanto à validade daquele Direito (particularmente dos Direitos das Gentes), se consideram por fôrça daquela competência geral, daquele processo de imputação, destinatários das normas, isto é, ponto de imputação dos direitos e deveres subjetivos daquele Direito objetivo, nem os indivíduos, nem outra pessôa jurídica, mas tão sòmente êles próprios, também êles próprios. Numa palavra: o Estado é soberano, desde que e até onde é ponto final de imputação".

19. R.C.A., vol. 102 e sua bibliografia. 
Já dissemos e repetimos, a soberania não é hoje um fantasma, mas sim uma realidade, como salienta muito bem VaN KLEFFENS ${ }^{20}$.

Històricamente a noção é antiga, o nome é que é moderno. A noção vem do Direito Romano. Liber et libertas: Liber autem populus est qui nullius alterius populi potestati est subjectus. - Paulo, Dig. xlıx. É a noção aceita por Grócio, De Jure l,F,c.2 §2.

É a soberania absoluta. A soberania relativa é conceito da Igreja e de Bobrn, que a limita pela lei divina e o Direito Natural. A doutrina de Bopin é a que prevalece hoje na restrição do Direito Internacional que foi criado pelo próprio Estado.

III.

\section{Intercurso.}

O intercurso é uma condição sem a qual não existiria uma família de nações.

O D.I. originou-se da interdependência de interêsses dentro da comunidade internacional.

O Direito das Gentes origina-se das necessidades da vida que influem, também, no seu desenvolvimento.

O comércio internacional foi, a principio, ùnicamente limitado aos poderes públicos. Incrementou-se, em seguida, o tráfego mercantil, origem de muitas normas do D.I..

As relações culturais aumentam dia a dia. Assim temos, de um lado, relações oficiais, de outro, relações privadas entre os povos. As relações internacionais são as que compreendem todos os contatos efetivos dentro da comunidade humana.

Estas relações internacionais derivam de necessidades permanentes da humanidade.

20. R.C.A., vol. 82 . 


\section{IV. \\ Interêsses humanos.}

O D.I. tende a regular não só as relações de Estados, mas sim as que se estabelecem dentro da comunidade humana.

O fundamento da obrigação de obedecer ao Direito está fora do campo do Direito. A base é moral porque o problema do caráter obrigatório do D.I. é um aspecto do problema do caráter obrigatório do Direito em geral, subordinado ao problema da obrigação em geral. É um problema ético.

"S'opposer à la violation des obligations morales attachées à l'idée d'humanité, tel est le but du droit international public", como dizia HolzENdorF nos seus Élements.

A Carta das Nações Unidas repetidamente trata da garantia dos direitos humano e das liberdades fundamentais ${ }^{21}$.

Não se pode dizer hoje que, de acôrdo com a Carta, um Estado pode tratar os seus cidadãos, de modo a desrespeitar os direitos humanos.

Quando estudarmos a influência dos progressos da técnica na transformação do D.I., verificaremos que ela atua no sentido do entrelaçamento dos interêsses humanos. Discutiremos então o problema palpitante do progresso moral e do progresso técnico.

\section{V. \\ Princípios gerais do Direito.}

O D.I. desenvolve-se com base em princípios morais, psicológicos e jurídicos coincidentes, conseqüência da identidade da natureza humana.

21. Preâmbulo e arts. 1 (3), 55, 62 (2), 68, 76. 
A Declaração Universal dos Direitos Humanos, aprovada pela Assembléia Geral da onu a 10 de dezembro de 1948, no art. 1, afirma que todos os seres humanos nascem livres e iguais quanto à dignidade e o Direito, sendo dotados de razão e consciência.

A positivação do Direito Natural são os princípios gerais do Direito do art. 38 do Estatuto do Tribunal Internacional.

A identidade da natureza humana tem como conseqüência o reconhecimento de valores comuns universais. É o reconhecimento de um valor espiritual para o Direito das Gentes.

A Carta das Nações Unidas e o Direito Internacional Geral.

I.

Terá a Carta das Nações Unidas abolido o Direito Internacional Geral? Se examinarmos o assunto, de acôrdo com KELSEN ${ }^{22}$, admitindo a validade simultânea de várias ordens normativas, podemos chegar a mais de uma solução.

Primeira solução:

A Carta é um tratado celebrado por Estados na base do D.I.P.. É, portanto, D.I. Particular, obrigatório no quadro do D.I.P., sòmente para os Estados Membros.

Segunda solução:

A Carta, art. $2 \S 6$, estendeu sua esfera de ação e aplicação aos Estados não membros da Organização, o que não é novidade em D.I. ${ }^{23}$.

E, assim, se a Carta aboliu o D.I.P., não tem mais razão o princípio de que o tratado só é obrigatório entre as partes.

22. (a) The Law of U.N., p. 770 ss.

23. Verdross, Volkerrecht, p. 145, KunZ, A.J., XLI 1947, 119 ss. 
Terá sido intenção dos Estados criadores da onU abolir o D.I.P.?

Se examinarmos acuradamente a Carta, verificaremos que regula apenas parte das relações entre os seus membros; quanto aos não membros, só há referência à manutenção da paz e da segurança.

Daí se presume claramente a continuação íntegra da validade do D.I.P..

Ainda mais claramente fica confirmada esta tese com a leitura do Preâmbulo da Carta e do Estatuto da Côrte que, de conformidade com o art. 92, é parte integrante da Carta.

São, assim, fontes reconhecidas, além dos tratados, os costumes e os princípios gerais do Direito reconhecidos pelos povos civilizados.

As decisões judiciais art. 38, do Estatuto, e a doutrina são fontes subsidiárias. Fica, assim, provada a continuação da validade do D.I.P..

Como a cláusula do art. $2 \S 6$ é norma obrigatória para os Estados não membros, foi ela uma criação revolucionária, como diz $\mathrm{KuNZ}^{24}$, o que se dá, também, no art. 103, da Carta.

Quanto aos direitos dados pela Carta aos Estados não membros, não há colisão com o D.I.P..

Veja-se o trabalho magnífico de Eduardo Jimenez de ARÉCHAGA ${ }^{25}$.

A Côrte Internacional já se pronunciou admitindo que as estipulações em favor de terceiros Estados não só podem ser invocados diretamente por seus beneficiários, mas conferem direitos definitivos e irrevogáveis em seu favor, enquanto não levianamente presumidos ${ }^{26}$.

24. A.J. cit. .

25. A.J., vol. 50 n..$^{2}$, abril 1956.

26. RIPERT. 417, R. 1 A. 595, 1933, Francoz, Rev. Dir. Público 1932, p. 743. Estuda: precedente do caso das Zonas Livres. Caso do tratado de Paz de 8 de Outubro 1824 entre o Brasil e a Argentina. Independência do Uruguai, v. PerEIRA PINTo, Apontamentos. 
O fundamento legal da estipulação em favor de terceiros é a regra "pacta sunt servanda".

Será a estipulação em favor de terceiro um princípio geral de Direito (art. 38, do Estatuto)?

Houve controvérsia no caso das zonas livres. A Carta não reconheceu a necessidade de transportar o princípio para o D.I.. Mas isso foi em 1930. Hoje a regra "alter stipular nemo potest" está superada, é um fantasma ${ }^{27}$.

0 resultado é o mesmo 28 .

Hoje a estipulação em favor de terceiro é um princípio geral do Direito, como salienta, com razão, AréchaGA ${ }^{29}$.

Hoje, enfim, não se pode mais duvidar que os tratados não conferem direitos ou obrigações a terceiros Estados. É fácil verificar ${ }^{30}$.

II.

A Carta é lex specialis. No caso do art. 51 a legitima defesa assume um caráter de guerra, limitada pelas normas de D.I.P..

Em 3 de novembro de 1950, houve uma orientação revolucionária: a Assembléia Geral recomenda aos membros as medidas de seguranẹa coletiva, quando o c. $\mathrm{s}$. não pode ou deixa de agir:

"A/1481 .... l'Assemblée Générale examinera immédiatement la question a fin de faire aux membres les recommendations appropriées sur les mésures collectives à prendre, y compris s'il s'agit d'une rupture de la paix en vue d'un acte d'agression, l'emploi de la force armée. ."

27. De PaGe, Traité de Droit Civil, v. II, p. 607, Planiol, Traité II, p. 123.

28. Conbin, Contraets for the Benefit of third Persons.

29. 46 Law Quarterly Review.

30. HAMBro, Lawo and Polities, p. 250. 


\section{As Recomendações.}

São eficazes, mesmo que se considerem só de efeito político e psicológico e não jurídico.

Não concordamos com Kelsev que não considera as normas sem sanção como jurídicas.

Caso contrário, as disposições do art. $2 \S 4$ seriam lex imperfecta para os membros permanentes do c. S.. Não teriam base jurídica.

No caso, os Estados membros agem discricionàriamente, limitados pelo D.I.P..

Éste é base e, além de preencher lacunas, concorre para a transformação do direito da Carta.

\section{História do Direito Internacional.}

OPPENHEIM, o insigne internacionalista e saudoso professor da Universidade de Cambridge, ao estudar a História do Direito Internacional ${ }^{31}$, afirma que o Direito das Gentes, considerado como um Direito entre Estados soberanos e iguais, baseado no consentimento comum dêsses Estados; é produto da moderna civilização cristã e tem apenas uns 400 anos de idade ${ }^{32}$. Essa é, parece-me, a teoria verdadeira. As origens do Direito Internacional, contudo, são antiquíssimas, são os usos e costumes adotados pelas nações antigas nas suas relações externas. Parece pouco provável que a idéia de uma Familia de Nações surgisse no limitado horizonte mental do mundo antigo. Cada nação tinha seus deuses, sua língua e sua moralidade próprias.

O estrangeiro era considerado inimigo. Não havia então interêsses internacionais que ligassem, com vínculo

31. Vol. 1, p. 48.

32. AXeL MöLLer, Int. Law, p. 7, 11, 44. 
inquebrantável, os Estados numa comunhão internacional. Entravam, contudo, as nações antigas em relações umas com as outras, faziam a guerra, celebravam a paz, enviavam embaixadores, aliavam-se e tais atos davam nascimento, está claro, a usos e costumes.

É essa a remota origem do Direito Internacional, mas êsses costumes, conquanto uniformes e interessantes para o Direito das Gentes, não poderiam ainda constituir o Direito Internacional, tal como é concebido modernamente. $O$ Direito Internacional pressupõe, como ensina AxEL Möller, a existência de vários Estados independentes, com certo nível uniforme de civilização, ligados entre si em uma comunhão internacional.

\section{Opiniões divergentes.}

De modo contrário pensam eminentes internacionalis$\operatorname{tas}^{33}$. O Barão KorfF, no curso que fêz em 1923 na Academia de Direito Internacional de Haia, sustenta tese contrária à de Oppenheim. Afirma que modernas investigações históricas provam que o mundo antigo conhecia perfeitamente o sentido das relações internacionais e aplicava um sistema de instituições muito desenvolvidas e firmemente estabelecidas. Apela para as leis de HammuRABI, os Papiros Egípcios, as Tábuas Babilônicas e Assírias, para sustentar a sua tese. E tira a conclusão de que o Direito Internacional é antiquíssimo, é uma conseqüência de tôda a civilização ${ }^{34}$. É a velha tese de Montes-

33. W. Beach LAWRENCE, Commentaire sur les Éléments du Droit Int. de Wheaton (1868), p. 99.

34. De grande utilidade para os que querem ter uma idéia exata dos fatos históricos é a consulta da monumental obra de BURET DE LoNGCHAMPS, Tableaux Chronologiques (MDCCCXxI) e F. LAURENT Etudes sur l'histoire de l'Humanité (18 vols.). Tenho, contudo, para mim que a História, longe de ser ". testis temporum, lux veritatis, vitae memoria, magistra vitae..." a que se refere Cíckno (De Oratore, 
QUIEU $^{36}$. Depois de afirmar que o Direito das Gentes é naturalmente fundado sôbre os princípios de que as Nações devem fazer na paz o máximo de bem possível e na guerra o minimo de mal possível, sem prejudicar os seus verdadeiros interêsses, afirma o genial escritor francês: "Tôdas as nações têm um Direito das Gentes e os próprios Iroqueses, que comem os seus prisioneiros, o têm. Enviam e recebem embaixadas; conhecem os direitos da guerra e da paz; o mal é que êsse Direito das Gentes não é fundado sôbre verdadeiros princípios".

Atribui KoRfF a opinião contrária à sua à ignorância das civilizações antigas por parte dos internacionalistas do Século xIx. Estas, segundo êle só, foram estudadas e ensinadas modernamente por ChyBichowsky, Vinogradoff, RosTOVTZEFF e outros.

Aponta casos para provar a antiguidade do Direito Internacional e de suas regras, sancionadas pela religião.

Considera, por exemplo, uma descoberta de Summer, de 4 mil anos antes de Cristo, e diz que recentemente se descobriu um tratado, assinado pelo rei EnTEMEna, regulando as fronteiras entre o seu reino de Lagash e o reino vizinho de Ummah.

Por êsse tratado, foi designado um árbitro, o rei MISILIN DE Kush. Eis aí o arbitramento. Recorre à História do Egito. Ramsés II concluíu em 1820 A.c. um tratado com o rei vencido dos Hititas, Hausilite, no qual aparece um

lib. II, cap. 36), é melhor caracterizada por GrBBoN quando diz: "History which is, indeed, little more than the register of the crimes, follies, and misfortunes of Mankind." (V.t. Nitri, La Dem. I, p. 90). Decline and fall of the Rom. Empire, ch. 3. NitTi (La Democratie, I, p. 82) mostra o absurdo de se dizer que a História é a mestra da vida. Sendo o estudo da História de grande auxílio para o Direito Int., consultar-se-á com vantagem, para a política européia: A. DEBIDoun Histoire Diplomatique de l'Europe. SEIGNoBos, Histoire Politique de l'Europe contemporaine.

35. De l'Esprit des Lois, L.1. I., cap. III. 
sistema perfeitamente regulado e complicado de extradição de refugiados políticos.

Ora, ninguém nega essas afirmações: o que se contesta é a existência entre os antigos de um Direito das Gentes, tal como é modernamente considerado.

De opinião semelhante à de KorfF é Nippold.

\section{Opinião de Nippold.}

No curso professado pelo grande internacionalista suisso Nippold, na Academia de Direito Internacional de Haia (1924), podemos acompanhar a sua argumentação.

Afirma que o Direito Internacional deve ser estudado sem preconceito, "sub specie aeternitatis", pois é um Direito que existiu em todos os tempos e no seio de tôdas as civilizações. Afirma com KorfF a antiguidade do Direito Internacional e que êle era conhecido pelas antigas povoações da África.

E contesta, além disto, que o Direito Internacional seja um produto da raça branca. O japonês UkiTA também diz que, se dermos crédito aos historiadores europeus, a História da Humanidade seria a história da raça branca.

Segundo o historiador Takahashi, o Japão, antes de ter relação com os europeus, já conhecia o Direito Internacional e aplicava suas regras. $O$ mesmo se poderia dizer da China, segundo W. Martin (China Kodai Bankoku Koho).

Conclui Nippold dizendo que a primeira lição a tirar do estudo da História do Direito Internacional é uma lição de modéstia. $O$ patrimônio que nos legaram as antigas civilizações é imenso e não devemos desprezá-lo.

Se o Direito Internacional deve muito à Moral Cristã, diz êle, não devemos esquecer que nos estados budistas se faz notar, quando se trata da História da Europa, que as guerras são mais numerosas nos Estados cristão. Com 
efeito, o Japão, durante 250 anos, e até a chegada dos estrangeiros, gozou de uma paz ininterrupta. Mas mitiga a sua opinião, dizendo que o cristianismo é uma religião tão pacífica como o budismo e que não se deve culpar nenhuma destas religiões pelos erros dos homens de Estado e da grande politica ou pelas lacunas do Direito das Gentes.

\section{Conclusão.}

KonfF e Nippold, segundo creio, não estão com a verdade. O Direito das Gentes é um produto da Moral Cristã, como dissemos atrás, acompanhando OpPENHeIM. Regras isoladas que regem relações entre os povos não constituem, ainda, o Direito Internacional, Direito que regula relações de uma "Família de Nações".

\section{Antiguidade.}

Como dissemos anteriormente, na antiguidade não encontramos o Direito Internacional tal como é concebido modernamente, pois é um produto da civilização cristã e tem apenas 400 anos de existência. Mas já então vamos encontrar os usos e costumes que mais tarde viriam a formar o Direito das Gentes.

Desde o princípio dos tempos históricos, o homem teve de entrar em relação com os seus semelhantes.

- Divididos em tribos, cuja grande lei era o isolamento, tinham os povos primitivos de entrar fatalmente em contato com os outros, pelo menos nas relações bélicas. Uma tribo guerreava com outra, faziam-se tratados para celebrar a paz, eram às vêzes enviados embaixadores, cuja inviolabilidade era sancionada pela religião. Iam, está claro, surgindo dessas relações alguns usos e, nos casos idênticos, procediam êsses povos da mesma forma, de tal sorte que 
êsses usos se transformavam paulatinamente em costumes internacionais.

É essa a remota origem do Direito das Gentes.

Vejamos quais eram êsses costumes entre os povos mais importantes da antiguidade.

\section{Os judeus.}

Tratemos, em primeiro lugar, dos judeus. Apesar de serem monoteistas e de muito mais elevada moralidade e civilização que os seus vizinhos, os judeus não tiveram grande influência no desenvolvimento do Direito Internacional. Desprezando as outras nações, o povo eleito não podia considerá-las como iguais. Apenas, no modo por que tratavam os estrangeiros, mostravam os judeus o seu elevado nível moral. Examinando-se alguns textos da Bíblia, vê-se que, com os escravos estrangeiros, eram mais brandos que todos os povos da antiguidade.

No Éxodo (XII - 20,26 e 27), encontramos os seguintes preceitos: " $O$ que ferir o seu escravo ou a sua escrava com uma vara, e êles lhes morrerem nas suas mãos, será culpado dêste crime". "Se alguém ferir o ôlho do escravo ou da escrava e os deixar cego de um dos olhos, os deixará livres pelo ôlho que lhe tirou".

No Deuteronômio (x - 19) se nos deparam os textos ordenando: "amai os peregrinos, porque também vós fostes estrangeiros na terra do Egito".

No Levítico (19, 33 e 34$)$ se preceitua: "Se algum forasteiro habitar na vossa terra e morar entre vós, não o impropereis; mas esteja entre vós, como se fôsse natural; e o amareis como a vós mesmos. Porque também vós fostes estrangeiros na terra do Egito". E, ainda: "Seja entre vós igual a Justiça, ou delinqüisse o forasteiro, ou o compatriota". 
Nas suas relações bélicas, faziam os judeus uma distinção interessante, assinalada por OPPENHEIM, entre os inimigos capitais e os simples inimigos ${ }^{36}$.

Com os seus inimigos capitais, os Amalecitas, por exemplo, eram de uma crueldade extraordinária ${ }^{37}$. Veja-se: Reis (I-15) - "Vai, pois, agora e fere a Amalec, e destrói tudo o que êle tiver. Não lhes perdôes a êles, e nem cobices coisa alguma sua: mas mata desde o homem até a mulher e o menino, e o que é de mama, o boi e a ovelha e o camelo e a ovelha".

No mesmo livrc, versículo $\mathrm{x}$ e seguintes, vemos Samuel, por ordem de Deus, repreender a SAuL por não o ter obedecido, fazendo passar a fio de espada os pecadores de Amalee. E logo em seguida vemos Samuel matar a AGAg: "xxxII - E disse SAmuel: trazei-me a Agag rei de Amalec. $\mathbf{E}$ foi-lhe apresentado AGAG, que era muito gordo e todo tremendo. E Agag disse: assim me separa a morte amarga? - xxxiI - E disse Samuel: assim como a tua espada tirou os filhos às mães, assim perderá a tua mãe entre as mulheres os seus filhos. E SAMUEL o dividiu em quartos diante do senhor em Galgala"38.

"II - Reis $(12$ - 31): E trazendo os seus moradores, os mandou serrar, e que passassem por cima dêles carroça ferrada: e que os fizessem em pedaços a cutelo e os botassem em fornos de cozer tijolos: assim o fêz com tôdas as

36. Duo Bellorum genere apud hebraeos: Quoedam Dei precepto necessaria, quoedam sponte suscepta. Primi generis Deo indicta, ut in Amalecitas, Chananeos... devotas gentes (Amalech-Agag Dictionarium Historicum Criticum - Calmet e Gallico in Latinum translatum. A Joanni D. Mansi Venetiis - MDCcxLVII).

37. EMILIo FERRIÈre, Los mitos de la Biblia, explica o mito de Lot e suas filhas como uma ficção odiosa para atacar os amonitas e moabitas (p. 164). F o mesmo FERRIère que explica pelo ódio internacional entre israelitas e cananeus a maldição de Canaan.

38. O horrível castigo contra Amalec vem descrito belamente por SoARES, Bahiense, Progynasma Litterario, p. 613, MDccxxXvil. 
cidades dos amonitas: e voltou DAvid com todo o exército para Jerusalem".

Quando entravam em luta com povos de que não eram mortais inimigos, procediam mais humanamente do que as outras nações da época. Assim, no Deuteronômio, encontramos as leis da guerra:

1) "Se saindo a fazer guerra contra teus inimigos e, tendo visto a sua cavalaria e as suas carroças, achares que o exército contrário é mais numeroso do que o teu, não o temerás: porque contigo está o Senhor teu Deus, que te tirou da terra do Egito.

2) E quando estiver perto de se dar a batalha, o pontífice se porá na frente do exército e falará assim ao povo:

3) ouve, ó Israel, vós estais hoje para combater contra os vossos inimigos não se atemorize o vosso coração, não temais, não recueis, nem lhes tenhais medo;

4) porque o senhor vosso Deus está no meio de vós e êle pelejará por vós contra os vossos inimigos, para vos livrar do perigo;

5) os oficiais, também cada um da frente do seu corpo, dirão, gritando, ouvindo o exército: Há algum homem que tenha edificado uma casa nova e não tenha ainda estreiado? Vá-se e torne para a sua casa: não suceda que êle morra no combate e outro a estreie;

6) há algum homem que tenha plantado numa vinha $\mathrm{e}$ ainda não a tenha feito comum, para que todos possam comer dela? Vá-se e torne para sua casa: não suceda que êle morra na peleja, e faça outro o que a êle lhe tocava;

7) há alguém que se tenha desposado com uma mulher e todavia a não tenha ainda em seu poder? Vá-se e torne para sua casa: não suceda que êle morra na batalha e algum outro a tome:

8) ditas estas coisas, acrescentarão êles e dirão ao povo o seguinte: Há algum medroso e de coração tímido? Vá-se e volte para sua casa: para não fazer desmaiar os corações de seus irmãos, assim como êle está assustado de medo. 
9) E logo que os oficiais do exército se calarem e acabarem de falar, cada um preparará os seus esquadrões para a batalha.

10) Quando te chegares para combater uma cidade, primeiramente lhe oferecerás a paz.

11) Se ela aceitar e te abrir as portas, todo o povo que houver nela será salvo e te ficará sujeito, pagando tributo.

12) Mas se não quizer aceitar as condições e começar a fazer a guerra contra ti, atacá-la-ás.

13) E quando o Senhor teu Deus te houver entregado às mãos, passarás ao fio da espada todos os varões que nela haja.

14) Reservando as mulheres e os meninos, os animais e tudo o mais que se achar na cidade. Distribuirás o esbulho todo pelo exército e sustentar-te-ás dos despojos de teus inimigos que o Senhor teu Deus te tiver dado.

15) Assim é que has de fazer a tôdas as cidades que estiverem muito longe de tí e não são daquelas que has de receber em possessão.

16) Quanto àquelas cidades, porém, que te hão de ser dadas, nenhum absolutamente deixarás com vida.

17) Mas os passarás todos a fío de espada, convém a saber, aos hetheus, e aos amorrheus, e aos cananeus, aos ferezeus, e aos heveus e aos jebuseus, assim como o Senhor teu Deus te mandou.

18) Para que não suceda que vos ensinem a cometer tôdas as abominações que êles mesmos fizeram a seus deuses e venhais a pecar contra o Senhor vosso Deus.

19) Quando te detiveres muito tempo no sítio de uma cidade, e a tiveres cercado com máquinas para a tomares, não cortarás as árvores de cujo fruto se pode comer, nem deves deitar abaixo a golpes de machado os arvoredos do país circunvizinho: porque isto são paus, e não homens, nem podem aumentar o número de teus inimigos. 
20) Mas se houver algumas árvores que não sejam frutíferas, mas silvestres e boas para outros usos, cortá-as e engenha delas máquinas, até que tomes a cidade que peleja contra ti".

Compare-se o procedimento dos judeus com o dos outros povos antigos e mesmo dos tempos modernos.

É verdade, como diz NiTTı (Dem. 2, p. 281), que nenhum povo agiu tanto sôbre a civilização moral do mundo como os hebreus: dêles é o nosso Deus e dêles, também, a nossa criação religiosa, o Cristianismo. Ainda dos hebreus nos veiu a sua criação moral, o socialismo. Êste povo insignificante que nunca conheceu o repouso, atormentado, perseguido, cada vez mais forte depois da ruina, cada vez maior depois das perseguições, é o que a civilização produziu de mais admirável. É não só a maior glória da civilização moral, como também uma das suas maiores fôrças de propulsão e de vida.

A superioridade dos judeus sôbre os outros povos é manifesta, e daí o antisemitismo.

Quase tudo que há de mais elevado na nossa civilização, na nossa moral, o sentimento de justiça e os mais sábios ideais de fraternidade humana, tudo isto é de origem hebráica ${ }^{39}$.

A guerra foi a relação normal entre os povos da antiguidade. Fazia-se ela de uma maneira crudelíssima. Lembremos o modo por que os assírios tratavam os vencidos. Diz Albert Malet" : "Os assírios eram impiedosos para com os vencidos. Infligiam-lhes os mais atrozes suplícios: furavam-lhes os olhos, cortavam-lhes o nariz, as orelhas, e os lábios, arrancavam-lhes a barba e as unhas ou, ainda, os empalavam e os esfolavam vivos. Elevavam troféus com cabeças cortadas. Atiravam os cadáveres às bêstas feras".

39. Clovis Bevilaqua, Estudos Jurídicos, p. 60-1.

40. L'Antiquité, p. 56. 
Vangloriavam-se os reis dêstes atos de selvageria: de dois matei um, diz Assurbanipal, e levei os sobreviventes como escravos. Construí uma pirâmide diante da porta da cidade. Esfolei vivos alguns dos chefes da revolta e estendi suas peles sôbre esta pirâmide. Outros foram emparedados vivos, outros empalados etc.. Sôbre as ruinas a minha físionomia expandiu-se, na satisfação do meu ódio encontrei o meu consôlo.

Os deuses da antiguidade eram sanguinários. O deus caldeu ou assírio era um senhor exigente e sanguinário, deuses dos seus povos como Istar, em Nínive, ou Mardur, em Babilônia. Para êles, os estrangeiros eram os inimigos ${ }^{41}$.

Lembremos uma inscrição de Assurbanipal: "os homens cuja boca tramará complôs, contra Assur e contra mim, tiveram a língua arrancada etc. Fazendo estas coisas, regosijei o coração dos deuses".

Faziam excepção na antiguidade os persas. Vencedores foram sempre dóceis e clementes para com os vencidos. Lembremos a bondade e a extrema generosidade de $\mathrm{CIRO}^{42}$.

Assim mesmo, podemos dizer que, sendo a guerra a forma normal das relações entre os povos da antiguidade, ela serviu de ponto de união para as civilizações.

O comércio era insignificante e não ligava os povos como atualmente. É por uma longa série de guerras que se penetraram as duas civilizações, a do Nilo e a do Eufrates.

Se o problema da paz internacional é, antes de tudo, moral, dependendo da perfeição da alma humana, ${ }^{43}$ podemos considerar o Decálogo a magna carta da humanidade civilizada.

O Cristianismo iria contribuir no futuro para realizar os ideais de paz e amor entre os homens. Tornando-se re-

41. Sôbre a origem do sacrifício, leia-se E. O. JAMES, Origins of sacrifice. A Study in Comparative Religion.

42. MaLET, citado, p. 122.

43. MöLLER, Cours de l'Académie de Droit International de la Haye. 
ligião universal, o cristianismo funde os princípios monoteistas da religião mais severa da antiguidade com o cosmopolitismo grego, obtido através da unidade do Império Romano: temos então a "Pax Romana".

Estava reservado ao Cristianismo tornar as nações conscientes do seu fim político comum e, em combate de alguns milhares de anos, pela evolução aperfeiçoadora da humanidade, estabelecer o fundamento do Direito Internacional e da Paz mundial.

Diz muito bem J. Mrller ${ }^{44}$ que a ação de propaganda intelectual e moral da Igreja cristã pela paz é importantíssima, ao lado do desejo constante de multiplicar as instituições pacíficas. Êste trabalho de propaganda é valiosíssimo. Só os ignorantes ou os de má fé negarão a importância extraordinária dela.

Wells, na sua linda obra Faillite de la Démocratie, salienta a necessidade e a importância de uma propaganda pacifista, como veremos mais tarde. É preciso, realmente, criarmos uma atmosfera psicológica sinceramente pacifista.

O Direito Internacional nasceu, a principio, no solo católico, é obra dos mestres espanhóis do Direito Natural, fundado na sabedoria de ARISTóteles e no trabalho filosófico de Santo Agostinho e de São Thomas de Aquino. Mas, depois de Grócio, sua formação foi feita quase exclusivamente pelos protestantes.

Realmente, todo movimento pacifista contemporâneo foi inspirado pelos protestantes inglêses e americanos. Não desprezando, conquanto menor, a importância da Igreja Ortodoxa, que teve no seu seio Dostorewsky e Tolstor, somos forçados a reconhecer a ação formidável das diversas seitas protestantes. Vejam-se a respeito as páginas eloqüentes escritas sôbre a política inglêsa nas Índias pelos protestantes a Pio Ix, e lembrem-se da ação de David Urquhart, inspirador da petição do Sínodo Patriarcal dos

44. Oeuvres des Églises pour la Paix. 
Bispos armênios de Constantinopla ao Concílio do Vaticano ${ }^{45}$.

Ainda hodiernamente causam admiração os ideais messiânicos (Isaias, II - 2-4) : "Em nos últimos dias estará preparado o monte da casa do Senhor no cume dos Montes e se elevará sôbre os outeiros, e concorrerão a êle tôdas as gentes.

E irão muitos Povos e dirão: vinde e subamos ao monte do Senhor e à Casa do Deus de Jacó e êle nos ensinará os seus caminhos e nós andaremos pelas suas veredas: porque de Sião sairá a Lei e de Jerusalem a palavra do Senhor.

E julgará as nações e argüirá a muitos povos: e das suas espadas forjarão relhas de arados, e das suas lanças foices; não levantará a espada uma nação contra outra nação, nem daí por diante se adestrarão mais para guerra".

\section{Os gregos.}

As nações, ou melhor, as cidades gregas, independentes e, ao mesmo tempo, interdependentes, dão-nos o primeiro exemplo de um Direito baseado no consentimento comum, que regula as relações recíprocas dos Estados soberanos ${ }^{46}$.

Antes da conquista macedônica, encontramos a Grécia dividida em uma porção de cidades independentes. Mas os gregos não se podiam esquecer de que tinham a mesma língua, a mesma raça, adoravam os mesmos deuses, eram animados por idênticos ideais de civilização. Por isso eram essas cidades independentes ou soberanas, interindependentes, formando uma comunhão internacional, uma verdadeira "Família de Nações".

45. DAVID URQUHART, Some Chapters in the life of a victorian Knight-errant of justice and liberty, by GERTRUDE RoBINsON, Oxford, 1920.

46. Catellani, Dir. Int., p. 15; Oppenheim, I, § 39. 
Conquanto cruéis nas guerras com os bárbaros, observavam entre si regras restritas de proceder e tinham usos internacionais muito brandos e humanos.

Reconheceram sempre a Santidade dos contratos e se observarmos que a religião era tudo na antiguidade, concluiremos que uma regra baseada em uma sanção religiosa estava muito mais garantida até do que atualmente quando certos governos declaram os tratados "trapos de papel".

Como faz notar NipPold, confundiam-se outrora o Direito e a Moral, mas essa confusão era menos nociva do que a invenção de um Direito Internacional amoral ${ }^{47}$.

Ao lado das Federações políticas gregas como a Liga anfictiônica, desenvolveu-se o belo Instituto do Arbitramento ${ }^{48}$. As práticas guerreiras, entre os gregos, eram brandas e não se fazia a guerra sem prévia declaração.

Pela neutralização de certas pessoas e lugares, contribui a Grécia para tornar a guerra menos desumana. Não conhecem os gregos o cortejo triunfal dos orientais e dos romanos, nem os troféus tomados no campo de batalha e que perpetuam a lembrança da guerra.

O modo de guerra dos helenos é muito mais civilizado do que o dos outros povos da antiguidade. Salienta J. MöLI.ER ${ }^{49}$, que, em relação aos orientais e aos judeus, a concepção grega da justiça e da guerra internacional justifica e representa um grande progresso. Os gregos não conhecem inimigos de Deus, no sentido oriental. Quanto ao destino dos povos, adotam de antemão a fórmula de Frederico Schiller: "A história é o Tribunal do Mundo".

47. A êsse propósito, diz GuMpLowicz: “A Moral é a própria vida e a fonte de Direito. O que hoje é Direito, ontem foi Moral, daí tôda a moralidade tender a tornar-se Direito. A moralidade é o Direito que domina na vontade popular". (Dr. Pollit., Fil. 3). Não é outra a lição de AXEL MöLLER: "Like all other law, International Law rests, in the last instance, upon an ethical basis", (I, p. 65).

48. ToD, International Arbitration amongst the Greeks (1913). RALSToN, International Arbitration from Athens to Locarno (1929).

49. Curso de Haya, vol. 31. 
Este ponto de vista é favorecido pelo fato de reinar entre os Estados gregos uma inconstância perpétua da fortuna militar. Uma tirania fundada ùnicamente na fôrça das armas não se podia prolongar muito tempo ${ }^{50}$.

A classe sacerdotal não era favorável às guerras. A sacerdotiza Theano ${ }^{51}$, cinco séculos antes de Cristo, na época da guerra de Peloponeso, recebe oficialmente a ordem de pronunciar fórmulas de maldição. Mas responde com dignidade: "Sou sacerdotisa para abençoar, e não para amaldiçoar".

Praticaram as cidades gregas a extradição de criminosos. Mesmo quanto aos estrangeiros, deram o exemplo instituições tendentes a protegê-los. Lembremos os proxenos, guardas da hospitalidade, e os tribunais para estrangeiros.

Não nos devemos esquecer do cosmopolitismo grego. Sócrates já dizia: "Sou um cidadão do mundo"; e, quatro séculos antes de Cristo, Sófocles coloca na bôca de sua Antigone a lei fundamental do amor ao próximo.

\section{Roma.}

Passemos a Roma. Por mais longe que investiguemos as instituições romanas, encontraremos uns sacerdotes, os Feciales, incumbidos de dirigir as relações de Roma com os

50. Mesmo com os outros povos, os gregos eram relativamente brandos na guerra. Exemplo, a generosidade de ALEXANDRE em relação a PoRo (Histoire Universelle - trad. de L'ANgLoIs par une Société de Gens de Lettres, Amsterdam et à Leipzig - chez Arks féc et Merkus - MDCCLI, vol. XIII, p. 70). Se notamos êste procedimento de ALEXANDRE, não podemos deixar, também, de nos referir a AsokA - V. NitTi, Dem. I, p. 321 .

51. Theano, sacerdotisa do tempo de Agraule - Plutarque Les vies des hommes illustres, tomo II, p. 263 (Alcibíades).

Sôbre Alcibíades: Justinus, Lib. 5., cap. 8, Xenophonte Histo. G.L.I., Thucidides, lib. 5.5.7.8. 
outros povos, aplicando um direito divino e sagrado, um "Jus Sacrale e Jus Feciale" 52.

Devemos distinguir nas relações de Roma com os outros povos dois casos principais :

1) Roma tinha tratado com o povo estrangeiro;

2) Roma não tinha com êle tratado algum;

Na primeira hipótese, as relações eram minuciosamenle reguladas pelo Direito.

Com o correr dos tempos, foi tal a quantidade de estrangeiros em Roma, que se formou para êles o "Jus Gentium", aplicado pelo "Praetor Peregrinus".

Os tratados de Roma com os outros povos eram:

1) de amizade (amicitia);

2) de hospitalidade (hospitium) ;

3) de aliança (foedus).

Às vêzes nos tratados se combinava que qualquer dúvida posterior seria decidida por árbitros, os recuperatores.

Quando não havia tratado de aliança, dominava o arbítrio. A pessoa que entrasse no território romano era escravizada e, assim, o romano que penetrasse no território estrangeiro era reduzido, também, à escravidão (exceto os embaixadores). Quando voltavam novamente à pátria, entretanto, os escravos se tornavam livres pelos "Jus Postliminii".

A guerra era uma instituição legal, com regras precisas. As justas causas de guerras eram:

1) a violação do domínio romano;

2) a violação dos embaixadores;

51. Accioly, § 47, Histor. Univ. par une société de Gens de Lettres, MdCCXLVII, p. 43 e 49, t. viIr. Em Tito Livio, $L$. I., cap. 25, vêm particularidades interessantes sôbre as atribuições dos feciais. Refere-se à decisão entre Roma e Alba, por meio dos Horácios e Curiácios, bem como ao tratado então celebrado, modêlo dos futuros tratados, que seriam celebrados pela cidade Eterna. 
3) a violação dos tratados;

4) o auxílio aos inimigos de Roma.

$\mathrm{E}$ sòmente começavam a guerra os romanos, se satisfações não fôssem dadas a Roma.

A guerra era sempre crudelíssima ${ }^{52}$. Terminava:

1) por tratado de paz;

2) pela "Deditio", e

3) pela "Occupatio".

"Ad instar" da "proxenia", existia em Roma o patronato, em virtude de que determinados estrangeiros ou povos tinham um defensor das suas pretensões legítimas em um cidadão romano.

O patrono de tôda a Sicília era Cícero.

Finalmente Caracalla aplicou a todos os habitantes do Império o Direito Romano.

Como veremos mais tarde, o Direito Romano, a razão escrita, muito influiu no desenvolvimento do Direito Internacional.

Não podemos dizer, contudo, que em Roma existisse um Direito Internacional como o concebemos modernamente ${ }^{53}$. 0 mesmo podemos dizer da Grécia. Na Grécia, o Direito Internacional tinha uma aplicação restrita: as Anfictiônias união para defesa dos seus interêsses comuns, dão-nos o exemplo de uma verdadeira Família de Nações.

Roma era um Império do Mundo (World Empire). E necessário para a existência do Direito Internacional uma base de costumes comuns e concepções jurídicas comuns.

52. O próprio CESAR não primava pela bondade. Apontaremos o seu procedimento no cêrco da Alessia e para com Vercingetorix. Mesmo com os heróicos hermínios procedeu ferozmente, como narra Manoel Faria e Souza, na sua História del Reyno de Portugal (En Bruxelas, MDCcxxx, cap. $x, p .71$ ), obra interessantíssima e digna de meditada leitura. NiTTI, La Dém. I. p. 366.

53. SÉfÉriadès, Cours, t. 34, p. 228. AXel Möller, p. 13. 
Diz muito bem DienA ${ }^{54}$ que uma sociedade de Estados, o que denominamos Comunhão Jurídica Internacional, só se forma quando existe uma pluralidade de Estados que entram em relações recíprocas, submetem-se a certas normas e têm uma comunhão de idéias morais e jurídicas, isto é, o que se denomina "consciência juridica comum".

\section{A Idade Média.}

Variam muito os historiadores na determinação das épocas históricas. Alguns prolongam a Idade Média até a renascença das letras e das artes, outros até a queda do feudalismo. Podemos, se atendermos ùnicamente ao desenvolvimento intelectual, limitá-la por SAnto Agostinho e BoÈcio, de um lado, por Bacon e Descartes, de outro (dominio da Escolástica).

Não erraríamos se a prolongássemos até a Reforma ou, ainda, até quase o fim do Século xv, em que são fatos notáveis o desabamento do Império do Oriente, a conquista de Granada, a invenção da tipografia, a união da Bretanha, o último grande feudo, a França, o descobrimento da América e o nascimento de LUTERo.

Adota-se vulgarmente a seguinte divisão da História: Antiguidade, desde os mais remotos tempos até a queda de Roma em 476; Idade Média, de 476 a 1453 (tomada de Constantinopla); Idade Moderna, de 1453 a 1789 (Revolução Francesa); e, Idade Contemporânea, de 1789 até hoje.

Como ensina KoRFF, os historiadores costumam dividir a Idade Média em dois períodos:

1. do Século $\mathrm{v}$ ao $\mathrm{x}$, ou "Idades Sombrias" (Darkages) e,

2. do XI ao XVI.

54. Derecho Internacional Publico, 1932, p. 7. 
Roma era um Império do Mundo (World Empire) que absorvia todos os povos antigos. Dificilmente poderiam os romanos conceber um Direito destinado a regular relações de Estados soberanos, pois êstes não existiam.

A religião cristã ainda veio aumentar a unidade do Império (momentâneamente). As coisas continuaram neste pé mesmo depois da divisão do Império (395).

Em 476, dá-se a queda de Roma ${ }^{55}$ e Romulus AugustuLus, o último imperador, é substituído pelo chefe bárbaro Odoacro, quando começa a Idade Média.

Os bárbaros invadem o Império. Nas Gálias surge o Reino dos Francos, com Clodoveu, em 476. Vencido Odoacro por Teodorico, 473, forma-se na Itália o reino dos Ostrogodos.

Em 456, o reino dos Visigodos é estabelecido na Espanha. Os vândalos formaram um reino na África, com Cartago por capital. Os saxões tomaram fé na Bretanha em 449.

Estes povos, que repartiam entre sí o Império, eram bárbaros e não estavam em condições de assimilar a cultura dos vencidos.

Muitos anos foram precisos para que se erguessem a um nível moral e intelectual próximo do romano.

Adotaram a religião cristã e a civilização romana, mas dificilmente poderiam pretender tornar-se romanos.

Há exagero, contudo, por parte daqueles que afirmam ter a cultura romana desaparecido inteiramente. Germens de cultura subsistiam aqui e alí, escolas e homens notáveis mantinham a tradição da cultura antiga. Lembremos sòmente BoÉcio e a Escola de Ravena, que atravessou todo êsse período de obscurantismo e, foi como que o ponto de partida da célebre escola de Bolonha (Clovis Bevilaqua, Estudos Jurídicos, p. 81).

Realmente, depois da queda do Império do Ocidente e durante os governos de Odoacro e dos Ostrogodos, a instrução manteve-se ainda ordenada, como ensina Federico Cicca-

55. Dialogos de varia historia, PEDRO DE MARIZ - MDCCXLIX. 
glione, na sua excelente História do Direito Italiano, o mesmo acontecendo com a reconquista de Justiniano.

Deixando de parte as minúcias, podemos dizer que nas províncias bisantinas da Itália, além de escolas que poderemos dizer secundárias, existiam as superiores para 0 ensino do Direito: Roma e Ravena.

A escola de Roma foi continuação da famosa Escola existente em Roma durante o Império e mantinha a mesma organização.

A escola de Ravena surgiu certamente depois de JustiNIANo, sendo impossível precisar a época do seu nascimento.

Discute-se ainda muito sôbre a origem da Universidade de Bolonha ${ }^{56}$. Parece-nos indubitável, contudo, que a Escola de Bolonha nada mais é do que transformação da de Ravena ${ }^{57}$.

Em 800, Carlos Magno restabeleceu novamente a unidade e foi coroado Imperador Romano pelo Papa Leão II.

56. G. Manacorda, Storia della scuola in Italia, Palermo, 1914.

57. Veja-se FEDERICo CiCCAGLIONE, Manuale di storia del Diritto Italiano. TARLAZZI, La Scuola di Diritto Romano in Ravenna, ed in Bologna. RICcI, Origini dello studio ravennato. RIVALTA, Discorso sopra la scuola delle leggi romane in Ravenna ed il collegio dei giureconsulti ravennati. Ravenna, 1888. ScHUPPER, Le Università ed il diritto, nel. vol. III dell'Opera: Gli albori della vita italiana, Milano, 1891. La scuola di Roma e la questione in irneriana, in Memorie della R. Accademia dei Licei, 1897. SARTI, De claris Archigymnasii bononiensis professoribus a saeculo $\mathrm{XI}$ usque ad saeculum XIV, Bonaniae, 17691772, n. ed. Bologna, 1889. Malagola, Monografie storiche sullo studio bolognese, in Bologna 1888. CHIAPPELLI, Lo studio bolognese nelle sue origini e nei suoi rapporti con la scienza preirneriana, Pistoia, 1888. GLoRIA, Autografo di Irnerio e origine delle Università di Bologna, Padova, 1888. TAMassia, Bologna e le scuole imperiali di diritto, in Archivio giuridico, 1888. PATELTA, La scuola giuridica constantinopolitana del secolo XI e la scuola di Bologna, negli studii storico-giuridici offerti a F. Schupfer, Torino, 1898. ZACHARIA vON LINGENTHAL, Il diritto romano nella bassa Italia e la souola giuridica di Bologna, in Rendiconti del $R$. Instituto Lombardo, 1885. RIVIER, L'Université de Bologne et la première rénaissance juridique, em Nouvelle Révue historique, 1888. 
O Império Franco durou pouco, pois em 845 , pelo tratado de Verdun, se fracionou em três partes, que foram o embrião de onde mais tarde se formariam as diversas nações européias.

Na Idade Média, poderia ter-se formado um Direito Internacional perfeito, como observa SÉFÉRIADÈs, mas isso, infelizmente, não aconteceu ${ }^{58}$.

\section{Nos Séculos XV e XVI.}

Nos Séculos xv e xvi, o Direito das Gentes torna-se indispensável na Europa. Nesse pequeno continente, surgiu uma multidão de Estados absolutamente independentes. Com o desenvolvimento extraordinário do comércio naquela época, estabeleceram-se relações entre os povos. Era indispensável que um Direito aparecesse para regular essas relações.

Fatores que influiram no desenvolvimento do Direito Internacional nessa época.

Ensina OPPENHEIM que em tal época sete fatos influiram grandemente no desenvolvimento do Direito Internacional. Vejamos quais foram:

1. Os civilistas e canonistas.

O renascimento do estudo do Direito Romano, com IrNerio, os glosadores e posiglosadores, que reputavam êste Direito, o Direito por excelência, a "Ratio Scripta" não poderia deixar de influir grandemente na formação de um Direito que se criava nessa época. Como a ciência grega, o Direito Romano desaparecera só aparentemente da Europa. Com a invasão dos bárbaros, povos ignorantes e devido ao

58. V. Axel MölleR, p. 13. 
proselitismo de uma nova religião, a filosofia grega, a ciência helênica transportou-se para a Ásia. Numerosos sábios e filósofos gregos refugiaram-se na Côrte Persa, e formou-se no Oriente importante núcleo intelectual que floresceu principalmente em Bagdá, enquanto baixava o nível mental europeu. Mais tarde, quando os árabes, derramando-se pelo Norte da África, se apoderaram da Espanha e vieram ameaçar tôda a Europa, que naturalmente dominariam, se os guerreiros de Carlos Magno não os tivessem detido em Tours, trouxeram todo o tesouro da filosofia e da ciência dos gregos e, assim, determinaram uma revolução no mundo, fomentaram a renascença, fizeram com que os modernos conhecessem as obras antigas: as científicas, sobretudo de Alexandria, e as filosofias da Grécia. Por êsse modo se estabeleceu ou, antes, se restabeleceu a unidade do pensamento científico e filosófico ${ }^{59}$.

Em relação ao Direito, observa Clovis Bevilaqua, as coisas se passaram de outro modo, mas o resultado foi o mesmo. O Direito Romano sempre dominou na Europa como lei. Não foi elemento posto à margem, atirado fora por algum tempo e descoberto por povos de outra origem que novamente o restituiram à Europa. Hoje a lenda da descoberta de um exemplar das Pandectas em Amalfi, ao tempo de Lotário II, está completamente desmoralizada depois dos estudos de Savigny sôbre a História do Direito Romano na Idade Média ${ }^{60}$.

É de notar que os civilistas consideravam o Direito Romano o Direito do mundo civilizado e tratavam de várias matérias internacionais, comenta o Corpus Juris.

Os canonistas, por sua vez, discorreram sôbre a guerra, procurando abrandá-la, torná-la mais humana ${ }^{61}$.

59. Clovis Bevilaqua, Estudos Juridicos, p. 74.

60. Clovis Bevilaqua, Estudos Juridicos. SavignY, Hist. du Dr. Rom. au Moyen Age, trad. Guenoux, 1830.

61. LAFAYETTE - $\$ \S 10$ e 11 . 
2. As coleções de leis maritimas.

No Século viII, começou o comércio marítimo a desenvolver-se e apareceram costumes maritimos, reunidos em corpos de leis. As mais notáveis dessas leis marítimas foram o Consolato del mare (sec. xiv) de Barcelona; as leis de Oleron (sec. XIII); a lei Rhodia (sec. vIII ou Ix); as leis de Wisby (sec. xiv), da ilha de Gothland na Suécia. Destas leis, a mais importante é o Consulado do mar (LAFAYETTE, p. 21).

3. As ligas de cidades. $\mathrm{O}$ terceiro fator foram as ligas de cidades para proteção de seu comércio. A principal delas è a Liga Hanseática ${ }^{62}$.

4. As embaixadas permanentes.

5. Os exércitos permanentes.

6. A renascença e a Reforma.

Diz muito bem Oppenheim $(1-60)$ que a renascença das ciências e das artes no Século $x v$, juntamente com a ressurreição do conhecimento da antiguidade, reviveu os ideais filosóficos e estéticos da vida grega e os transferiu para a moderna. Surgiu a convicção de que os princípios cristãos deveriam ser observados tanto em matéria nacional como internacional. De outro, lado, a reforma pôs fim à supremacia do Papa sôbre o mundo civilizado.

Os Estados protestantes não poderiam reconhecer mais o poder arbitral do Papa. Se é verdade que o Código da Ética Cristã contido no Novo Testamento serve como regra de proceder nas relações internacionais e como ponto de referência para se saber se um procedimento é justo ou injusto, conforme ensina Davis ${ }^{63}$, pode-se calcular a influência extraordinária da Reforma, considerada por Calvo como um dos mais notáveis acontecimentos da História do mundo.

62. BÜTLER and MACCOBY, p. 24.

63. International Law, p. 28. 
Ensina NrTTi ${ }^{64}$ que os homens que vivem na nossa civilização obedecem às mesmas paixões e seguem em parte os mesmos instintos que os seus antepassados. Sòmente as idéias morais e os sentimentos de ordem elevada determinam grandes movimentos da humanidade e contribuem para o seu aperfeiçoamento.

Interpretações arbitrárias de hipóteses científicas, como o transformismo, a evolução, a hereditariedade das qualidades adquiridas, durante muito tempo entretiveram as ilusões mais absurdas. O que há de melhor em nós, o que atenua a violência dos instintos, das paixões, é apenas o fruto das grandes concepções morais e religiosas. O próprio socialismo não pôde implantar-se sòlidamente senão nos países penetrados do espírito de Israel e da Civilizaçẫo cristã.

Esta influência extraordinária da Reforma no Direito Internacional será por nós estudada detalhadamente em tempo oportuno.

Conquanto Grócio procurasse remontar o Direito das Gentes aos gregos e romanos, autores modernos não aceitam tal tese. O sonho de dominação universal, acalentado pela Roma antiga, era a negação do Direito Internacional.

A Igreja herdou de Roma ${ }^{65}$ o desejo da unidade, aspirando organizar a Monarquia Universal.

64. La Démocratie, 1933, p. 12.

65. VirgiLIo (Eneida, I, 278; Iv, 227, 231; vI, 851-853) proclamava o destino de Roma: exercer uma soberania à qual os deuses não impuseram nenhum limite, no espaço e no tempo. DANTe, seguindo o poeta, proclamava a missão de Roma divina e sua história um milagre da Providência. O prestígio de Roma era tal que Bartolo taxava de herético quem duvidava que o imperador da Alemanha fôsse imperador do mundo. Sendo a cidade eterna sede do Império Universal, devia o próprio Cristo ser considerado romano (Div. Com., Purg. 102). De Monarchia II, 4 e NitTI, (La Dém., 2. ${ }^{\circ}$, p. 277) descreve magistralmente a luta entre a Igreja Católica e o Estado. Mostra o grande escritor que a Igreja de Roma, onde tudo se vende (DANTE, Par. xviI, 51), nunca deixou de sonhar com a dominação universal. Em uma democracia, o regime da separação da Igreja e do Estado é o único meio 
A Igreja cedeu mesmo à tentação de reivindicar o reino dêste mundo, idéia repelida por Cristo (S. Matheus - 48).

Apontemos os Papas. Gregorio vir condena o poder temporal dos Príncipes (Epistolae, Lib. viII, I - 21), sendo o papado o Sol e a realeza a Lua; o sacerdócio tendo sido instituído por "ordinationem divinam" e a realeza por "extorsionem humanam", o poder sacerdotal é superior ao civil, como a alma ao corpo. Durante tôda a Idade Média, a Igreja trabalhou por obter o predomínio dessa tese teocrática da unidade do mundo ${ }^{66}$.

Triunfasse a Igreja e o Direito Internacional não poderia se desenvolver sob sua influência, como observa FAUchille (vol. I, p. 73). O absolutismo eclesiástico é ainda muito mais perigoso do que o leigo, pois se funda na vontade insondável de Deus, e não conhece limites.

A unidade desejada pela Igreja é incompatível com o Direito Internacional, e a Igreja era no fundo inimiga das Nações. Estas se constituiram graças à Reforma, quando os príncipes se opuzeram às pretenções dos Papas. A Reforma estabelecendo a autoridade da Escritura Santa, concorreu para excitar a atividade intelectual do povo e para sua instrução, bem como para o aparecimento das literaturas nacionais. A reforma foi que fêz penetrar na vida moral dos povos no século XvI as idéias de liberdade religiosa e de liberdade politica. Dela se originam tôdas as liberdades modernas $^{67}$.

de existirem os dois poderes sem conflitos permanentes. 0 conflito histórico entre a Igreja e o Estado só pode ser solucionado pela separação completa e com a liberdade religiosa plena, absoluta, irrestrita. Sempre que o catolicismo dominou soberanamente, abafou a liberdade e impediu o progresso econômico e social (p. 279). Não nos devemos esquecer nunca de que "l'opposition fondamentale entre catholicisme et démocratie, entre catholicisme et liberté ne disparaîtra jamais..." (NiTTi, La Dém., 2., p. 284).

66. LAURENT, Études sur l'histoire de l'humanité, tomo vI, p. 109.

67. Les grandes démocraties modernes sont nées dans des pays de civilisation chrétienne; mais dans des pays où le catholicisme s'était atténué, où il ne dirigeait plus avec autorité l'tetat, chez des popula- 
MAX BoEGNer ${ }^{68}$ diz que, constituídas as nações, devido à Reforma, a ciência do Direito das Gentes data do Século xvi. Sòmente então, os Estados secularizados se tornam sujeitos de Direito, e as relações múltiplas que sua coexistência no seio de uma mesma comunhão humana os obriga a estabelecer entre si, na plenitude de sua soberania, dão ao Direito Internacional o objeto sem o qual êle não poderia existir. Grócıo recebeu, como em geral os reformados das provínciais unidas, uma forte cultura bíblica. Assim recorre, na sua argumentação, à autoridade divina e cita freqüentemente a Bíblia. Os sucessores de Grócı nos Séculos xvil e xviII, Zouch, Puffendorf, Barbeyrac, BurlamaQUI, Wolf, WatTel, todos são protestantes e durante dois séculos o Direito Internacional aparece, como salienta BOEgNER, como sendo uma ciência reformada.

Entre todos êstes internacionalistas protestantes existe a convicção de que os deveres internacionais são uma cate-

tions qui, sous l'effet du protestantisme, s'étaient éloignées du catholicisme (NITTI, La Démoeratie, vol. II, p. 247). “Dans les pays d'Europe et d'Amérique, prèsque tous les grands mouvements politiques qui ont déterminé la formation des démocraties modernes, sont sortis des luttes religieuses contre l'église catholique, et ils ont pris naissance souvent dans des pays protestants" (id. p. 249).

Esta é a tese do grande NiTrI, que mostra que o fator religioso desempenhou grande papel no nascimento da democracia, sendo sempre um movimento exterior ao catolicismo e mesmo contrário a êle (p. 249 e 254). Da mesma forma o Budismo, na sua essência antes uma filosofia que uma religião, rebaixa o nível da vida, alimenta nas almas um quietismo mórbido, e, conquanto tenha uma moral altíssima, não contribui de forma alguma para a emancipação humana (p. 249).

"On peut dire que le principe de la liberté moderne, liberté de penser, de se reunir, de discuter, d'avoir une opinion, de la divulguer et de l'enseigner - liberté substantielle de l'individu, indépendente de l'État et de l'Église, ont peut dire que cette liberté n'est venue que de la réforme protestante, et que seul l'esprit de la réforme protestante a fait surgir en Amérique la première grande république et la première constitution vraiment démocratique". (NITT, La Dém. 2.0, p. 270).

68. MAX BOEGNeR, Cours VI, p. 262. 
goria dos deveres cristãos. A atuação pacífica dos reformados foi constante através dos tempos.

Lutero detestava a guerra. ERASmo e Calvino foram pacifistas e êste condena a guerra como coisa horrível e contra a natureza, uma enormidade. Calvino formula claramente as leis da guerra, e diz que um povo, levado a uma guerra de defesa, não deve esquecer nunca a solidariedade humana e que todos somos irmãos (Opera, p. 619). Tôda crueldade deve ser evitada, respeitadas também as árvores e tudo que serve de alimentação ao povo. A guerra para Calvino não se estende aos não combatentes, cujas vidas devem ser respeitadas. Os Quakers desejavam transportar os preceitos de Jesus Cristo relativos ao perdão das ofensas, à não resistência, à paz, para o domínio das relações internacionais.

Entre êles se salientam Wiliam Penn e Antonio Benezet. A organização internacional teve como pioneiros sempre homens imbuídos nos principios da Reforma. Sintetizando o magnífico curso na Academia de Direito Internacional de Haia, em 1925, em que tratou da influência da Reforma sôbre o desenvolvimento de Direito Internacional, MAX BoEgner, pastor da Igreja reformada da França, assim se expressa: “Ainsi s'est exercée depuis le xvième siècle, ainsi s'exerce encore aujourd'hui sur le developpement du droit international l'influence des Églises de la Réforme. Parce qu'elle est, non pas une Réforme entreprise et achevée en un moment dans l'histoire, mais un mouvement, un esprit qui porte en lui une force inepuisable de croissance, de renouvellement et d'approfondissement. La Réforme après avoir rendu possible et soutenu de tout son effort la formation de nations independentes, devait necessairement découvrir la sauvegarde de cette independence dans une société des nations garantissant à chacune le respect de ses droits essentiels. Elle continuera dans l'avenir, par fidélité aux grands principes de l'Évangile du Christ, a rendre la coopération des peuples dans un commum labeur pour fonder la vie internationale, dans tous les domaines, sur la recon- 
naissance de la valeur sacrée de la personne humaine et des exigences de la solidarité"69.

7. Os projetos de paz perpétua ${ }^{70}$.

Dêles nos ocuparemos mais tarde. Por agora advertiremos sòmente que não são puras quimeras. RousseaU, no "Jugement sur la paix perpetuelle", - salienta, sôbre o projeto de Sully, que o seu primeiro autor é Henrique iv, que nada tinha de insensato, e Sully, que estava longe de ser um visionário. $\mathrm{O}$ sistema era apenas bom demais para ser adotado: “. . ce qui est utile au public ne s'introduit guère que par la force, attendu que les interêts particuliers y sont presque toujours opposés". (Oeuvres politiques de J. J. Rousseau, vol. $3 .^{\circ}$, éd. 1821).

Poderíamos dividir a história do Direito Internacional de diversas formas, segundo critérios vários. Limitarnos-emos, porém à estudar a evolução de Direito das Gentes nos seguintes períodos:

do século Xvi até fins do século xviII;

do século xvirI até a guerra do 1914;

desta até hoje, abrangendo a segunda conflagração mundial.

O Direito Internacional forma-se no continente europeu quando se constituem os Estados modernos.

Como veremos a consolidação dos Estados nacionais deve-se a Luis XI, de França, Henrique viII, da Inglaterra, e Fernando de Aragão, da Espanha.

69. JACQUES DUMAS, Les Origines Chrétiennes du pacifisme contemporain (Paris, 1914). N. WeIss, La Démocratie et le Protestantisme (Paris, 1924).

70. OPPENHEIM, I, $\S 42$, n. 7, p. 61. 


\section{Literatura.}

TAUBE, Les origines de l'arbitrage international, R.c.A., t. 62 Van Kan, Droit de la paix, R.c.A., t. 66.

\section{Do Século XVI até fins do Século XVIII.}

Surge, então, a oportunidade para a criação do Direito Internacional moderno.

A estrutura política medieval transforma-se completamente. As coletividades políticas libertam-se da supremacia do Papa e do Imperador.

Já nos referimos ao papel desempenhado na França por Luis XI, na Inglaterra por Henrioue viII e Fernando de Aragão, na Espanha.

"Le Roi de France est Empereur en son Royaume. Le Roi n'a point de souverain dans les choses temporelles".

É a afirmação do poder político supremo do Príncipe. Ao mesmo tempo, formam-se nos Estados nacionais línguas e literaturas diversas.

Na Idade Média, a língua era única, a latina. Começa então o particularismo das línguas como afirmação de individualismo político. É o que se dá hoje na Noruega, na Irlanda e em Israel.

Como dissemos anteriormente, a formação dos Estados nacionais é impulsionada pela Reforma.

Concentra-se o poder político.

Cada vez mais se cristaliza a idéia de um poder instituído, inerente à idéia do Estado.

A base territorial torna-se importante para caracterizar o Estado.

Com a concentração do poder, o Principe encarna o Estado.

71. Machiavel, $O$ príncipe. 
O Principe é onipotente e pode mesmo tirar a vida de seus súditos, sem justa causa ou qualquer forma de juízo.

No trabalho de Mignet, Antonio Perez et Philippe II, temos uma carta do confessor de Philippe II, Diego de Chaves, sôbre a morte de Escovedo.

"Segundo minha opinião sôbre as leis, o Príncipe secular que tem poder sôbre a vida dos seus súditos, assim como pode tirar a vida dêles por meio de julgamento regular, pode fazê-lo sem justa causa e sem nenhuma formalidade. Deve-se acreditar que a ordem dada pelo Príncipe é sempre justa".

Identifica-se o interêsse do Principe e o interêsse do Estado.

No capítulo xiv do Principe, Machiavel diz que o Príncipe deve dedicar-se à guerra, pois a personalidade do Príncipe se mede por seu valor militar.

A família do Príncipe se identifica com o Estado e dai políticas dinásticas e numerosas guerras. São as guerras de sucessão, como a da sucessão de Espanha.

Surge então a noção de soberania do Estado. Em 1576, Boprn, nos Seis Livros da República, lança a teoria da soberania.

No tempo de Bodin, a guerra civil enfraquecera muito o poder na França e êle se preocupou com a necessidade de reforçar o poder para assegurar a ordem.

Apresenta então a doutrina da soberania, "summa potestas" ou "majestas".

A doutrina da soberania aceita impede o desenvolvimento do Direito das Gentes. Esta idéia de soberania ainda é acentuada no Leviathan de HoBBes.

A doutrina caracteriza-se pelo aparecimento dos teólogos espanhóis, Vitoria e SuARez. Procuram conciliar a concepção cristã da unidade do gênero humano com o fato histórico da distribuição do poder entre os Estados soberanos, mesmo com o conceito aristotélico que vê no Estado uma comunidade perfeita e a forma mais elevada das sociedades humanas. 
Na Idade Média, SÃo Tomás dE AQuino escreve sôbre a paz e sôbre a guerra.

Preocupados em dar indicações úteis aos diretores de consciência dos Grandes, principalmente a coroa espanhola, nos Séculos xv e xvi, os teólogos espanhóis examinam problemas internacionais e salientam que os reis, conquanto onipotentes, não têm um poder arbitrário.

\section{Vitoria.}

Vitoria, que viveu de 1480 a 1546 , era um dominicano espanhol, que ensinou em Salamanca. Suas lições, recolhidas pelo seus alunos e publicadas depois de sua morte, tratam de problemas internacionais com grande visão.

No trabalho $D e$ indis noviter inventis, determina os direitos e os deveres espanhóis em relação aos selvagens do Novo Mundo.

No De jure belli hispanorum in barbaros, enumera os casos e o modo de luta armada contra os índios da América.

Rejeita VIToRIa o conceito medieval do Direito Internacional. Não admite um título de dominação universal do Imperador, nem que os espanhóis tenham poder sôbre os índios em virtude da Bula Pontifícia Inter caetera.

Considera os índios, apesar de não-cristãos, como parte da sociedade humana universal que existe entre os cristãos e os não-cristãos; desta sociedade natural resultam os direitos, notadamente de comércio, de imigração etc...

\section{Suarez.}

O jesuíta Suarez viveu de 1548 a 1616 e ensinou em Coimbra. Escreveu o trabalho De legibus ac Deo legislatore. O trabalho de SuArez engloba o conjunto do problema das leis e do Direito Natural e dá uma definição de 
Direito Internacional, escoimada de elementos religiosos e válida ainda hoje: "Conquanto cada cidade independente, cada reino, constitua em si uma comunidade perfeita e formada por seus membros, nenhuma destas comunidades deixa de fazer parte do conjunto que é o gênero humano. Jamais estas comunidades podem separadamente bastar-se a si mesmas, sem ter necessidade do auxílio das outras, de onde a união, seja para aumentar o bem-estar, seja por utilidade ou por uma necessidade moral".

Dai se conclui que a ligação entre as comunidades não deriva do Direito Natural mas resulta das considerações sociológicas.

Diz Suarez: "por êste motivo tem necessidade de algum Direito que as reja convenientemente neste gênero de relações e de sociedade".

Aparece, portanto, o Direito como conseqüência de relações que se estabelecem necessàriamente entre as coletividades distintas que fazem parte de uma sociedade maior.

Vemos, assim, o elemento utilitário ligado ao princípio ético, que funda o Direito na crença de uma harmonia necessária de interêsses.

Gentilis, Grócio, De Martens.

Outros escritores tratam dos problemas do Direito Internacional, principalmente escritores protestantes.

Tratando de estudar o Estado, Bodin examina os problemas referentes aos tratados, território, guerra etc., utilizando-se de dados fornecidos pela prática.

Alberico Gentilis (1552-1608), de origem italiana, pertence ao número dos escritores protestantes. Filho de pai protestante que se exilou na Inglaterra. Professor em Oxford, foi advogado dos espanhóis perante os tribunais de prêsas inglêses.

Estudou os problemas de um ponto de vista prático e escreveu em 1588 o De Jure Belli, onde estuda o problema 
da legitimidade da guerra, servindo-se da prática do seu tempo. E, por conseguinte, um positivista porque se baseia nas regras efetivamente aplicadas pelos Estados em suas relações.

Outros escritores partem de considerações filosóficas na busca da regra internacional.

Vejamos o maior de todos, Hugo Grócio.

Nascido' na Holanda, em 1583 (Delft), fêz seus estudos em Leyde e, mais tarde, em Orléans. Foi poeta, filosófo, polemista, humanista e jurista. A principio, envolveu-se nas lutas religiosas, combatendo os calvinistas e a predestinação. .Preso em 1619, quando Barneveld foi decapitado, foi condenado a prisão perpétua. Dois anos mais tarde, evadiu-se espetacularmente em uma caixa de livros, preparada por sua mulher. Refugiou-se na França, onde permaneceu até 1631, data da morte de Maurício de Nassau. Em 1634, torna-se embaixador da Suécia em Paris, voltando à Suecia em 1645. Morreu em um naufrágio, emRostock (1645).

Em 1604, escreve o De Jure Praedae, consulta redigida para a Companhia das índias.

Mais tarde, um capítulo do De Jure Praedae, o Mare Liberum (o mar livre), foi utilizado para protestar contra a pretensão da Grã-Bretanha que queria impedir aos holandeses a pesca no mar do Norte. Grócio afirma que o mar é um bem comum a todos, que deveria estar aberto a todos, que o alto mar é livre.

Esta doutrina não estava de acôrdo com a prática da época e só triunfaria no Século xviır.

A obra capital de Grócıo, escrita na França e publicada em 1625, é o De Jure Belli et Pacis (Do Direito da guerra e da paz), dedicada a Luis xill e que teve extraordinário sucesso. Escrito em latim, o livro de Grócıo teve numerosas edições e, no Século xviII, foi traduzido por BARBEYRAG.

O De Juri Belli é a obra que maior importância teve depois da Bíblia. Encontra-se nela a noção de Direito 
Natural que tamanha importância teve na formação do Direito das Gentes. Por isso é que Grócio é denominado Pai do Direito Internacional e Pai do Direito Natural.

A noção do Direito Natural vem do Direito Romano pois o "jus civile" é um sistema de Direito estreitamente ligado à organização política de Roma.

Para estender as relações juridicas a outros que não os cidadãos romanos, imaginaram a existência de princípios que limitassem a conduta dos homens, baseados na natureza do homem, ser racional e social, não vinculados a uma forma política. Estes princípios impõem-se aos homens porque o homem é um ser racional e social. Esta noção do Direito Natural permitiu aos romanos ampliar um sistema jurídico além do Direito aplicado aos cidadãos romanos. Quando se fala em "jus gentium" quer-se significar que êste é, de certo modo, o "jus naturale", o Direito Natural aplicado aos que não eram os cidadãos romanos.

Na Idade Média, Santo Thomaz de Aquino ensina que o Direito Natural é a parte da Lei Divina que a razão humana pode descobrir.

Esta idéia de que, fora da existência de uma sociedade política, existem princípios obrigatórios foi aplicada às relações dos Estados.

Com a influência do Direito Romano que se fêz sentir na Renascença, considera-se que o Direito Romano é a Ratio scripta.

O efeito do grande tratado de GRócio foi profundo. Assim, na Paz de Westfalia, os seus princípios foram reconhecidos e tornaram-se verdadeiramente o fundamento da nova ordem na Europa, estabelecida em 1648, pelos tratados de Osnabruck e Münster.

No fim do Século xvi já De Jure Belli et Pacis foi traduzido para várias línguas e, no Século xviır, já 45 várias edições latinas haviam aparecido.

Grócıo admite a influência de seus precursores, principalmente Gentilis. Grócro, como seus predecessores, 
acredita que existe um Direito da natureza universal e imutável.

Como o Direito da natureza se aplica aos Estados e a indivíduos, podemos concluir que Grócıo considera o Direito Internacional como aplicável não sòmente aos Estados mas também aos individuos.

Ao contrário de HobBes que sustenta que não existe um padrão universal de justiça e que a utilidade é o que caracteriza a lei, Grócıo afirma a existência de uma justiça divina e uma essência moral na natureza das coisas.

As relações internacionais são para GRócro sujeitas ao Direito da natureza e também governadas pelo "jus gentium", estabelecido pelo consenso da comunidade das nações.

Separa assim Grócıo o Direito natural do "jus gentium". Este que, para os romanos, era o "common law" das Nações, tornou-se para Grócio um corpo de normas costumeiras oriundas do tácito consentimento dos Estados membros da comunidade internacional.

\section{Ricardo Zouche (1590 - 1660).}

Outros autores encontramos no Século xviI, entre êles Ricardo Zovche, que succedeu a GentiLis como professor em Oxford.

25 anos depois de Grócio publicar o de Jure Belli et Pacis, Zouche escreve o seu Jus et Judicium Feciale, Sive Jus Inter Gentes, considerado o primeiro manual de Direito Internacional, na opinião de Georges Scelle.

Conquanto Zouche não negue a existência do Direito Natural, salienta, entretanto, a importância dos precedentes originados do intercurso entre os Estados, verdadeiramente o alicerce do Direito das Gentes.

Podemos classificá-lo com Gentilis como um dos fundadores da escola positivista do Direito Internacional que

72. Cf. Fondateurs du Droit International, p. 322. 
considera a prática dos Estados nas suas relações reciprocas como a verdadeira fonte de Direito Internacional.

Não nos esqueçamos de que foi Zouche o primeiro a distinguir claramente o Direito da guerra e o Direito da paz, dando ao último uma preeminência patente e decisiva.

As três escolas do Direito Internacional.

Da distinção entre Direito Natural, tratado por GRócıı e os teólogos espanhóis, e o Direito Positivo ou Costumeiro de Gentilis e Zouche, surgiram as três escolas de Direito Internacional.

São elas a Naturalista, a Positivista e a Eclética ou Grociana.

A primeira é conhecida, também, como escola do Direito Natural; a segunda como escola Histórica e a terceira, como dissemos, Eclética (Herchey, The Essentials of International Public Law and Organization, p. 72).

73. OPPENHEIM-LAUTERPACHT, p. 90. 